\title{
biomolecules
}

ISSN 2218-273X

www.mdpi.com/journal/biomolecules/

Review

\section{Mechanisms of Alpha-Synuclein Action on Neurotransmission: Cell-Autonomous and Non-Cell Autonomous Role}

\author{
Marco Emanuele and Evelina Chieregatti * \\ Department of Neuroscience and Brain Technologies, Istituto Italiano di Tecnologia, 16163 Genoa, \\ Italy; E-Mail: marco.emanuele@iit.it \\ * Author to whom correspondence should be addressed; E-Mail: evelina.chieregatti@iit.it. \\ Academic Editor: Stephan N. Witt
}

Received: 16 March 2015 / Accepted: 29 April 2015 / Published: 13 May 2015

\begin{abstract}
Mutations and duplication/triplication of the alpha-synuclein ( $\alpha \mathrm{Syn})$-coding gene have been found to cause familial Parkinson's disease (PD), while genetic polymorphisms in the region controlling the expression level and stability of $\alpha$ Syn have been identified as risk factors for idiopathic PD, pointing to the importance of wild-type (wt) $\alpha$ Syn dosage in the disease. Evidence that $\alpha \mathrm{Syn}$ is present in the cerebrospinal fluid and interstitial brain tissue and that healthy neuronal grafts transplanted into PD patients often degenerate suggests that extracellularly-released $\alpha$ Syn plays a role in triggering the neurodegenerative process. $\alpha$ Syn's role in neurotransmission has been shown in various cell culture models in which the protein was upregulated or deleted and in knock out and transgenic animal, with different results on $\alpha$ Syn's effect on synaptic vesicle pool size and mobilization, $\alpha$ Syn being proposed as a negative or positive regulator of neurotransmitter release. In this review, we discuss the effect of $\alpha$ Syn on pre- and post-synaptic compartments in terms of synaptic vesicle trafficking, calcium entry and channel activity, and we focus on the process of exocytosis and internalization of $\alpha$ Syn and on the spreading of $\alpha$ Syn-driven effects due to the presence of the protein in the extracellular milieu.
\end{abstract}

Keywords: alpha-synuclein; exo/endocytosis; calcium entry; non-cell autonomous; lipid microdomains 


\section{Introduction}

Alpha-synuclein ( $\alpha \mathrm{Syn})$, a small protein of 140 amino acids specifically enriched in the presynaptic nerve terminals [1], has been found as a major component of Lewy bodies, with intraneuronal inclusion present in the brain of Parkinson's disease (PD) patients [2,3]. Human $\alpha$ Syn protein consists of three distinct structural motifs. The scheme in Figure 1 depicts $\alpha$ Syn's structure. The N-terminal region (residues 1-61) contains four of the seven imperfect repeats of the KTKEGV motif, reminiscent of the lipid-binding domain of apolipoproteins, which, in certain conditions, forms amphipathic helices that associate with vesicles containing phospholipids [4], such as the synaptic vesicles membrane, both in vitro and in vivo. It is the region where missense mutations linked to early onset familial PD have been found. Binding to the membrane determines a stabilization of the protein structure, due to the increase in amphipathic $\alpha$-helix content from 3\% to over 70\%. Mutations in the sequence coding for the $\mathrm{N}$-terminal domain determined a mislocalization of $\alpha$ Syn and a detachment from the plasma membrane in yeast [5]. The central core (residues 62-95) is a hydrophobic region (non-amyloid- $\beta$ component or NAC domain), which is responsible for aggregation and toxicity. The NAC domain comprises the highly amyloidogenic part of $\alpha$ Syn [6,7], which mediates its conformational change from a random coil to a $\beta$-sheet structure. The $\mathrm{C}$-terminus (residue 96-140), rich in acidic and proline residues, interacts with several proteins [8] and contains sixteen residues repeats, which could be important for $\mathrm{Ca}^{2+}$-binding [9]. The $\mathrm{C}$-terminal region tends to decrease protein aggregation, displaying an opposite effect to the NAC domain. Indeed, truncated forms of $\alpha$ Syn lacking the C-terminal tail ( $\alpha$ Syn $1-120)$ are more prone to aggregation [10,11]. Many posttranslational modifications of $\alpha$ Syn occur at the C-terminus, such as phosphorylation of Ser129 or nitration of Tyr125, Tyr133 and Tyr136. These modifications may alter $\alpha$ Syn protein conformation, promoting oligomerization and filament formation [12,13]. $\alpha$ Syn belongs to the intrinsically-disordered protein (IDP) family, a group of proteins that lack an organized secondary structure [14]. For its peculiar propensity to undergo structural changes, according to the different environment in which it is found, Syn has been referred to as a "protein chameleon" [15]. For this reason, Syn may be unfolded in solution, may assume an $\alpha$-helical structure when bound to lipids or may fold into $\beta$-sheet-like structures, when aggregated. The IDPs are known to be involved in numerous interactions with multiple partners. Therefore, they frequently serve as nodes or hubs in protein interaction networks, where they are central to the normal function and stability of the network [16]. $\alpha$ Syn is a typical IDP, in fact adopting different conformational states and interacting with more than 50 others proteins [17], interactions that, in turn, may cause changes in $\alpha$ Syn conformation [18,19]. It is still not known if the multitude of binding partners competes for similar binding sites, interacts differentially according to Syn conformation or binds in a competitive/allosteric binding and if these bindings take place in specific subcellular compartments. Although $\alpha$ Syn's physiological role is unknown, some evidence suggests a potential implication in the exocytic process [20], in the recycling of synaptic vesicles [21] and in the regulation of synaptic transmission [22]. 


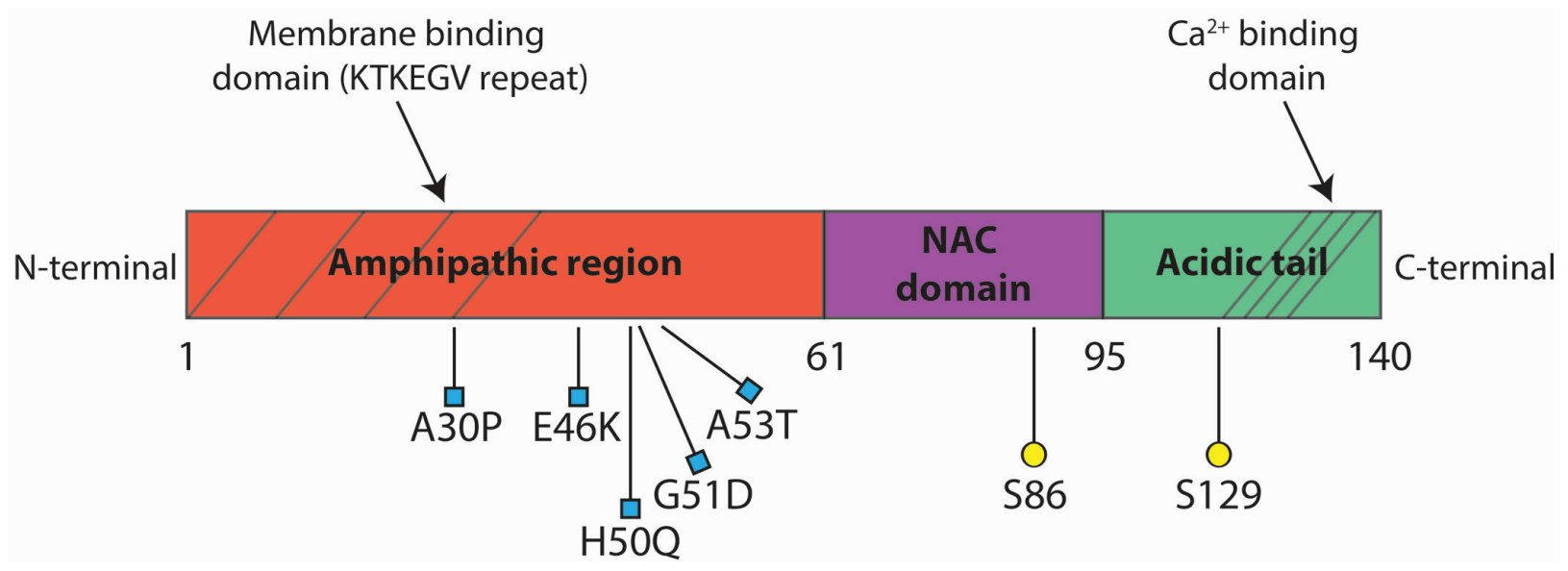

Figure 1. Structure of the $\alpha$ Syn protein. The N-terminal domain (red) is composed of KTKEGV repeats where human missense mutations associated to familial PD have been found. The central hydrophobic core (purple) is called NAC domain and promote aggregation of the protein. The $\mathrm{C}$-terminal domain (green) is the acidic tail that contains phosphorylation sites and the calcium binding site.

\section{2. aSyn Pathological Species}

\section{1. aSyn Aggregation}

In the Lewy bodies, $\alpha$ Syn is found in fibrillar aggregates [23], and some evidence indicates that the oligomeric and fibrillar $\alpha$ Syn species are responsible for the toxicity and the spread of neurodegenerative diseases [24]. The mechanism involved in aSyn oligomerization seems to be influenced by different factors, such as the levels of $\alpha$ Syn expression [25], the form of $\alpha$ Syn (wild-type or mutated) [26], $\mathrm{pH}$ and temperature [18,27], the concentration of some metals (i.e., aluminum) [28], and also by environmental agents, like pesticides [29]. In the Lewy bodies, $\alpha$ Syn adopts a $\beta$-sheet structure that is highly organized. In vitro studies showed that the oligomerization process is nucleation dependent, starting from $\alpha$ Syn monomers or dimers to the anti-parallel $\beta$-sheet [30]. Initially, the protein changes its conformation from unfolded to partially folded oligomers. This conformational change permits the exposure of the NAC domain that starts the aggregation process through hydrophobic interactions. Monomers are rapidly added to the initial nuclei with the formation of large oligomers, protofibrils and, at last, fibrils [18]. Cellular processes altered by the presence of fibrillar $\alpha$ Syn species whose impairment leads to neuronal toxicity and death and are well studied: reduction in the size of the presynaptic vesicular pool [31], mitochondrial dysfunction [32], increase of the level of intracellular reactive oxygen species [33], formation of pores in the plasma membrane [34,35] and the inhibition of the ubiquitin-proteasome system [36].

\section{2. $\alpha$ Syn Mutations}

The $\alpha$ Syn gene, $S N C A$, is located on chromosome 4q22.1 and contains six exons encoding the 140-amino acid of the protein. The first genetic evidence for the involvement of SNCA in PD was the identification of three missense mutations (A30P, E46K and A53T), which segregated with the disease in unrelated families and caused PD with high penetrance [37-39]. Up to now, another two mutations (H50Q, G51D) have been discovered in the $\alpha$ Syn gene [40-43]. 
The different mutations exhibit distinct effects on the rate of progression of PD. For example, patients carrying the A30P mutation show a late and mild form of dementia, whereas carriers of the A53T mutation are affected by a severe form of parkinsonism frequently associated with dementia [38,44]. Moreover, Conway et al. showed that A53T aSyn in vitro fibrillizes more rapidly than the wild-type form, while A30P aSyn fibrillizes more slowly [45]. H50Q mutation has been shown to increase the rate of $\alpha$ Syn aggregation, whereas the G51D mutation has the opposite effect, despite the early onset of disease in PD patients bearing the G51D mutation. Indeed, both $\alpha$ Syn mutants can form intracellular aggregates starting from internalized amyloidogenic preformed seeds [46]. Jensen et al. were the first to show that the A53T form, unlike the A30P form, maintains the ability to bind vesicles and membranes [4]. However, in some conditions, the different mutations have the same pathological effect. Tanaka et al. using an in vitro cell culture demonstrated that the expression of the A30P form leads to a decreased activity of the proteasome complex after seven days [47]. Nonaka and Hasegawa showed a similar inhibition of the proteasome activity in SH-SY5Y expressing A53T $\alpha$ Syn. The ability of the mutant forms of $\alpha$ Syn to inhibit the proteasome activity is probably related to the propensity of $\alpha$ Syn to assemble into filaments [48]. Additionally, the expression of both A30P and A53T $\alpha$ Syn make the cells more vulnerable to oxidative stress $[49,50]$ or dopamine toxicity [51].

\section{3. $\alpha$ Syn Dosage}

Although mutations in the $\alpha$ Syn gene have been implicated in the progression of PD, recent genetic and biochemical data suggest that an increase in the level of the expression of wild-type $\alpha$ Syn is sufficient to cause neurodegeneration [52]. Ross et al. in their work showed that patients with $S N C A$ duplications often exhibit a classical PD phenotype. On the other hand, the more rare cases of triplications exhibit a more severe phenotype, showing a direct relationship between SNCA gene dosage and pathology [53]. Devine et al. in their work used induced pluripotent stem cells (iPSCs) derived from patients with triplication of the SNCA locus. These patients display PD symptoms, and their iPSCs differentiated into dopaminergic neurons express double the amount of $\alpha$ Syn. The increase in $\alpha$ Syn expression might be responsible of the disease in these individuals [54]. In another study, Flierl et al. demonstrated that iPSCs with $S N C A$ triplication, once differentiated into the neuronal precursor, exhibit normal cellular morphology, but showed changes in growth, viability and stress resistance. More importantly, $\alpha$ Syn silencing by shRNA rescues these phenotypes [55].

$\alpha$ Syn levels may also have a role in the pathogenesis of sporadic PD; nucleotide polymorphisms, highly associated with PD and affecting $\alpha$ Syn levels by altering gene transcription or mRNA stability, were recently identified. Moreover, genetic variations in the promoter region, in the REP1 dinucleotide repeat, previously found to regulate Syn expression, appear to modulate PD risk [56,57]. Interestingly, the selective vulnerability of dopaminergic neurons in the substantia nigra with respect to the neurons of the ventral tegmental area may correlate with the increased Syn levels found in these neurons in aged monkeys and humans [58].

\section{4. aSyn Post-Translational Modifications}

$\alpha$ Syn undergoes several post-translational modifications, which have a potential role in $\alpha$ Syn aggregation and toxicity. Phosphorylated [13], Tyr-nitrated [12] and methionine-oxidized [59,60] products of $\alpha$ Syn 
are found in Lewy bodies, as well as truncated forms of the protein, obtained by calpain I cleavage [61]. $\alpha$ Syn is constitutively phosphorylated at various serine residues, with serine 129 (S129) as the major phosphorylation site [62]. Numerous studies showed that S129 is phosphorylated in more than $90 \%$ of the insoluble $\alpha$ Syn present in Lewy bodies, whereas the phosphorylation is present only in $4 \%$ of normal $\alpha$ Syn [13]. Many authors identified different kinases mediating $\alpha$ Syn phosphorylation at S129. Okochi et al. produced evidence that S129 is phosphorylated by casein kinase 1 and casein kinase 2 [62]. Pronin et al. in their study demonstrated that $\alpha \mathrm{Syn}$ is a substrate of $\mathrm{G}$ protein-coupled receptor kinases (GRK). Moreover they showed that GRK-mediated phosphorylation inhibits the interaction of $\alpha$ Syn with phospholipids and phospholipase D2, suggesting a functional role for this specific modification [63]. The function of this post-translational modification is not completely clear. Waxman and Giasson suggest that phosphorylation in S129 blocks aSyn fibrillization [64]. Chen and Feany using the Drosophila model of PD showed that mutation of S129 to alanine to prevent phosphorylation completely suppresses dopaminergic neuronal loss produced by expression of human $\alpha$ Syn. Consistently, mutation of S129 with the negative residue aspartate, which mimics phosphorylation, increases $\alpha$ Syn toxicity [65]. Moreover Visanji et al. demonstrate that the phosphorylation state of S129 can influence the ability of aSyn to bind synaptic membrane [66]. Recently, also, phosphorylation in serine 86 (S86) was characterized. Paleologou et al. suggest in their study that phosphorylation at S86 maintains $\alpha$ Syn as unfolded, blocks its fibrillization in vitro and reduces the binding of $\alpha$ Syn to membranes [67]. It is has been shown that $\alpha$ Syn purified from Lewy bodies is partially ubiquitinated [68]. Ubiquitination is a process that controls numerous aspects of protein function, such as degradation, protein-protein interaction and subcellular localization [69]. Nonaka et al. report that in vivo aSyn is ubiquitinated at lysine 6,10 and 12. Moreover, they showed that fibrils of aSyn are less ubiquitinated than the soluble form and suggested that de-ubiquitination may have implications for the formation of $\alpha$ Syn toxic forms [70]. In recent studies, quite a few aggregation-prone proteins implicated in neurodegeneration were found to be SUMOylated, and SUMOylation-deficient mutants showed an enhanced tendency to aggregate [71]. Krumova et al. showed that SUMOylation of $\alpha$ Syn is able to delay protein aggregation [72]. Furthermore, Kunadt and collaborators proposed that SUMOylation of $\alpha$ Syn is directly involved in the release of the protein in the extracellular space [73].

\section{Physiopathological Role of $\alpha$ Syn in Neurosecretion}

Considering that the physio/pathology of $\alpha \mathrm{Syn}$ is strictly dependent on its level of expression and ensuing propensity to aggregate, it is fundamental to study the anatomical and ultra-structural distribution of $\alpha$ Syn. $\alpha$ Syn is expressed in many types of cells, both neuronal and non-neuronal. Indeed, $\alpha$ Syn is especially expressed in hippocampus, olfactory bulb, striatum and cerebellum [74,75], but also in the peripheral nervous system at the level of the olfactory system, retina and auditory system [76]. From the point of view of neuronal specificity, $\alpha$ Syn is not exclusively expressed in monoaminergic neurons of the CNS, as first described in [77], but it is also ubiquitously expressed in cholinergic, GABAergic and glutamatergic neurons [78]. aSyn was detected also in other cell types than neurons, such as astrocytes [79], oligodendrocytes [80], macrophages [81], endothelial cells [82] and platelets [83]. Regarding its localization in neurons, $\alpha$ Syn was first identified in association with synaptic vesicles and in the nucleus [1], where it binds histones [84,85], and only later the subcellular fractionation of mouse brain revealed $\alpha$ Syn presence in the cell body and in neurites [86]. The localization of $\alpha$ Syn in neuronal cell bodies early in development followed by a 
redistribution to the nerve terminals, suggests that $\alpha$ Syn is involved in synaptogenesis [87]. The delayed localization at synapses is consistent with the idea that $\alpha$ Syn may function in the maintenance, rather than in the formation, of synapses [31]. The function of $\alpha$ Syn is not clear, and the mechanism by which it leads to pathology is poorly understood. Based on the findings of $\alpha$ Syn enrichment at the presynaptic compartment and of its loose association with synaptic vesicles, a role for this protein in neural transmission has been hypothesized [88,89]. Since its identification, $\alpha$ Syn has been demonstrated to be involved in synaptic plasticity [90]: upregulation of $\alpha$ Syn has been associated with the process of learning in experimental animals, such as song-learning in birds [91,92]. Even though $\alpha$ Syn is highly soluble, it binds to a diversity of cellular membranes and proteins with different properties. These interactions are considered critical for the physiological function of $\alpha$ Syn [93].

\subsection{Synaptic Vesicles and Transmitter Release}

$\alpha$ Syn's role in synaptic vesicles homeostasis is well characterized, and a large number of studies point out $\alpha$ Syn's involvement in every phase of the synaptic vesicle cycle, including trafficking, docking, fusion and recycling after exocytosis. Murphy et al. demonstrated that a reduction in $\alpha$ Syn expression after treatment of a neuronal cell culture with antisense oligonucleotide led to a reduction in the size of the presynaptic vesicular resting pool [94]. Abeliovich et al. established a aSyn knock-out mouse model. They showed that $\alpha \mathrm{Syn}^{-/-}$mice are viable and with no changes in brain architecture. Moreover, dopaminergic neurons are healthy and do not present anomalies in the release or uptake of dopamine. However, these mice display an incremented release of dopamine upon paired pulse stimulation and ensuing altered dopamine-dependent locomotor response to amphetamine [22]. These works suggest that $\alpha$ Syn is a negative presynaptic regulator of neurotransmitter release that would restrict the traffic of synaptic vesicles from the resting pool to the sites of release. Consistently, it was shown that an increase in the refilling of the ready releasable pool of vesicles in the striatum of $\alpha \mathrm{Syn}^{-/}$mice or of mice expressing the A30P $\alpha$ Syn mutated form [95] also showed a reduced size of the resting pool [96]. This kind of negative regulation appears not confined only to dopamine release. Experiments with transgenic mice overexpressing A30P $\alpha$ Syn or with different strains of $\alpha$ Syn knock-out mice revealed an altered norepinephrine mobilization [97]. Furthermore, other studies suggested the idea that the lack of $\alpha$ Syn also impairs the mobilization of glutamate from the reserve pool and that, on the contrary, the expression of the A30P mutated form of $\alpha$ Syn does not exhibit this effect [98]. Experiments of $\alpha$ Syn overexpression link this protein also to vesicle trafficking. In PC12 cells, the overexpression of wild-type $\alpha$ Syn causes the accumulation of docked vesicles, suggesting an inhibition of the priming of neurosecretory vesicles, which are unable to fuse [99]. In hippocampal neurons, it has been shown that the overexpression of $\alpha$ Syn impairs the re-clustering of synaptic vesicles after endocytosis [100].

Another $\alpha$ Syn-null mouse yielded results apparently inconsistent with the above interpretation. In their mouse model, Cabin and collaborators [101] showed that the absence of $\alpha$ Syn correlated with an impaired response to tetanic stimulation, due to deficient refilling of the ready releasable pool, possibly due to a reduction in the size of the resting pool. The further characterization of a double knock-out mouse model, lacking both the $\alpha$ - and $\beta$-isoform of the synuclein family, evidenced no impairment in basic brain functions or survival, with no alteration in synapse morphology, in synaptic plasticity, in the size of synaptic vesicle pools or in synaptic vesicle recycling. Differently from the single $\alpha$ Syn knock-out model, double knock-out 
mice showed a characteristic decrease of dopamine levels in the brain, with no change in uptake and release. These data suggest that the synuclein family is not an essential component of the synaptic machinery, but may contribute to more subtle long-term regulation and/or maintenance of function at the presynapse [102]. Recently, data about a triple-knock out mouse lacking the three $\alpha$-, $\beta$ - and $\gamma$-isoforms of synuclein have been reported. These mice showed altered synaptic structure and transmission, age-dependent neuronal dysfunction and diminished survival. In particular, a 30\% decrease of the size of excitatory synapses was observed. A further characterization of triple knock-out mice evidenced a non-correct formation of the Nethylmaleimide-sensitive factor (NSF) attachment proteins (SNAPs) receptor family of proteins (SNAREs) complex $[103,104]$. In particular, $\alpha$ Syn binds to synaptobrevin2/vesicle-associated membrane protein 2 (VAMP2), thus promoting SNARE's assembly. The hypothesis that $\alpha$ Syn acts to support SNARE complex assembly and functioning during aging seems in accordance with its putative physiological role at presynaptic terminals.

Finally, some other studies sustained that $\alpha$ Syn may positively regulate synaptic transmission, by acting on the late steps of exocytosis. In cysteine string protein alpha (CSP $\alpha)$ knock-out mice, transgenic expression of $\alpha$ Syn was shown to rescue the function of SNAREs, abolishing the lethality that takes place in these mice [20]. In hippocampal neurons, the introduction of $\alpha$ Syn enhanced both spontaneous and evoked neurotransmitter release, while its deletion by antisense oligonucleotides blocked the potentiation of synaptic transmission [105]. In knock-out animals, in the absence of $\alpha$ Syn was reduced the frequency and amplitude of synaptic currents in neurons of area CA1 of the hippocampus, but only in highly demanding conditions, when the release probability was high [106].

Lundblad and collaborators used in vivo amperometry to monitor changes in synaptic dopamine release in the striatum induced by the injection of an adeno-associated virus-type vector carrying $\alpha$ Syn in nigral dopaminergic neurons. They showed that the impairment in dopamine release correlated with damage in nigrostriatal axons and terminals. After three weeks from the injection, the first signs of axonal damage were visible, and the amount of dopamine released after a $\mathrm{KCl}$ pulse was reduced by $70 \%-80 \%$. After $8-16$ weeks, the overall striatal innervation density was reduced by $60 \%-80 \%$, and the presence of $\alpha$ Syn aggregates was shown. At this stage, dopamine release was reduced by $80 \%-90 \%$ [107]. Several mechanisms have been proposed regarding the possible role of $\alpha$ Syn in the regulation of vesicles trafficking. Ahn et al. in their study demonstrated that $\alpha$ Syn is capable of binding phospholipase D2 (PLD2) and inhibiting its activity [108]. PLD2 catalyzes the hydrolysis of phosphatidylcholine to generate the lipid second messenger, phosphatidate and choline and is implicated in the regulation of vesicle trafficking in terms of endo- and exo-cytosis [109]. Moreover $\alpha$ Syn can indirectly inhibit PLD2 through its binding to proteins that regulate PLD2 activity, such as extracellular signal-regulated kinase (ERK) or 14-3-3 protein [110]. Another key player in the regulation of neurotransmitter release is the actin cytoskeleton. Actin microfilaments are essential for synaptic vesicle mobilization between different functional pools, for their organization at the active zone, thus influencing the exocytotic process. Actin has been suggested to act via multiple mechanisms. Actin microfilaments could arrange tracks along which the vesicles travel or bring the vesicles on top of the waves of polymerization. Actin filaments could also act as a physical barrier opposing exocytosis. Moreover, actin is required to cluster the molecular complex essential for vesicles fusion. Recent studies suggested that $\alpha$ Syn binds actin, modulating its polymerization in a manner dependent on $\mathrm{Ca}^{2+}$ concentration [111]. A30P $\alpha$ Syn alters the rate of actin polymerization and perturbs cytoskeleton morphology and dynamics, leading to alterations in the exo-/endo-cytic traffic [112]. 


\subsection{Calcium Entry}

$\mathrm{Ca}^{2+}$ is a highly versatile intracellular signal that regulates many different cellular processes and plays a pivotal role in neuronal plasticity and survival [113]. The network that regulates intracellular calcium level is extremely complex, and $\mathrm{Ca}^{2+}$ signals depend on its influx from the extracellular space together with its release from intracellular stores, such as the endoplasmic reticulum [114]. Neurons express a multitude of $\mathrm{Ca}^{2+}$-binding proteins. $\mathrm{Ca}^{2+}$ sensors decode and differentiate between various $\mathrm{Ca}^{2+}$ signals according to differences in the localization, $\mathrm{Ca}^{2+}$ affinity and kinetics of ion binding [115]. $\mathrm{Ca}^{2+}$ clearance mechanisms in neurons control the duration, as well as the spread of $\mathrm{Ca}^{2+}$ signals and result in the reduction of free cytoplasmic $\mathrm{Ca}^{2+}$ and in the restoration of its basal level during recovery from stimulation [116]. An abnormally-increased $\mathrm{Ca}^{2+}$ concentration demands intense $\mathrm{Ca}^{2+}$ buffering, a demand that is not met by aging neurons. Rapid $\mathrm{Ca}^{2+}$ sequestration is attributed to $\mathrm{Ca}^{2+}$-binding protein buffers in the cytoplasm, such as calbindin, calretinin and parvalbumin.

Recently, deregulation of this network has been correlated with neurodegeneration occurring in sporadic Parkinson's disease (PD) [117]. Surmeier et al. showed that epidemiological data support a linkage between $\mathrm{Ca}^{2+}$ channels and the risk of developing $\mathrm{PD}$. The main dopaminergic midbrain subpopulation affected in PD is a subpopulation of 'A9' nigrostriatal neurons, while neurons, including the 'A10' dopaminergic neurons of the ventral tegmental area (VTA), are largely spared. Dopaminergic neurons expressing higher levels of protein buffers calbindin, calretinin and parvalbumin seem to be resistant to degeneration in PD [118-120] and in the 1-methyl-4-phenyl-1,2,3,6-tetrahydropyridine (MPTP)-treated mouse model [121]. Moreover, selective vulnerability of substantia nigra pars compacta (SNc) dopamine neurons to aging-related $\mathrm{Ca}^{2+}$ dyshomeostasis has recently been supported by the observation that pacemaker firing in these cells relies on L-type voltage-operated $\mathrm{Ca}^{2+}$ channels (VOCCs), as opposed to juvenile cells, which rely on $\mathrm{Na}^{+}$channels. Prolonged activity of L-type VOCCs in older neurons may lead to $\mathrm{Ca}^{2+}$ overload and contribute to neuronal ageing and death. Moreover, they pointed out that L-type VOCCs elevate the sensitivity of dopamine neurons to mitochondrial toxins used to create animal models of $\mathrm{PD}$, suggesting that $\mathrm{Ca}^{2+}$ entry is a key factor in their selective vulnerability [122].

Studies on the effect of $\alpha$ Syn on $\mathrm{Ca}^{2+}$ homeostasis have been mainly conducted by using $\alpha$ Syn oligomers. $\alpha$ Syn aggregates potentiate neuronal $\mathrm{Ca}^{2+}$ dyshomeostasis and overload [123-125]. Various works showed an increase of $\mathrm{Ca}^{2+}$ in basal conditions, possibly due to a pore-forming mechanism [125], and an alteration in membrane conductance due to leak channel formation [126], consistent with in vitro evidence demonstrating the formation of pore-like structure in synthetic membranes [127].

Furukawa et al. reported that in a neuroblastoma cell line, the expression of both A30P and A53T mutant forms of $\alpha$ Syn increases the plasma membrane ion permeability. Both the basal level of $\mathrm{Ca}^{2+}$ and the level after membrane depolarization are greater in cells expressing mutant of $\alpha$ Syn, and the $\mathrm{Ca}^{2+}$ chelator 1,2-bis(2-aminophenoxy)ethane-N,N,N',N'-tetraacetic acid (BAPTA-AM) significantly protects the cells from oxidative stress [128]. In the SH-SY5Y cell line expressing wt or the A53T mutant $\alpha$ Syn, $\mathrm{Ca}^{2+}$ entry through L-type VOCCs was increased, and store-operated $\mathrm{Ca}^{2+}$ entry (SOCE) following store depletion was suppressed [129]. Martin and collaborators in their study demonstrated that $\alpha$ Syn oligomers can increase intracellular $\mathrm{Ca}^{2+}$ levels, inducing calcineurin activity, which leads to death of human neuroblastoma cells. They also showed a consistent effect when $\alpha$ Syn oligomers were applied to organotypic brain slices or in mice after acute intracerebroventricular injections [130]. 


\subsection{Membranes}

Due to its lack of transmembrane domain or lipid anchor, Syn has been considered a peripheral membrane protein. However, multiple studies led to the observation that Syn is able to bind phospholipidic membrane and free fatty acids, both in vitro and in vivo. It is well known that in vitro aSyn binds artificial membrane, in particular those containing acidic phospholipids. The N-terminal region of $\alpha \mathrm{Syn}$ is able to bind synthetic lipid vesicles and to detergent micelles in vitro and mediates its transition from random coil to an $\alpha$-helical structure, while the C-terminal part of the protein does not associate with either vesicles or micelles, remaining unstructured $[89,131-134]$. The missense mutations linked to familial forms of PD occur at the N-terminal domain of aSyn. Unexpectedly, both A30P and A53T $\alpha$ Syn do not significantly affect the structure of membrane-associated $\alpha$ Syn, while E46K shows an increase in $\alpha$ Syn affinity for an artificial membrane [135]. Interaction of $\alpha$ Syn with membranes has been investigated in vivo by several groups. $\alpha$ Syn interacts with membranes at the synapse, but in a transient, rapid and reversible manner [136]. On the contrary, the A30P mutation greatly diminishes the propensity of Syn to bind to native membranes $[4,137,138]$. Fortin et al. demonstrated that $\alpha$ Syn associates specifically with lipid microdomains resistant to low-temperature detergent solubilization, the lipid rafts [139]. Importantly, they showed that the A30P mutant lost the ability to interact with synaptosomal membranes and redistributed away from the synapse. This suggests a role for raft association in the physiological function of the protein [140]. Neuronal activity controls both the synaptic localization and membrane association of $\alpha$ Syn. Upon the entry of $\mathrm{Ca}^{2+}$ that triggers the exocytic process, $\alpha$ Syn rapidly disperses away from synaptic boutons, dissociating from synaptic vesicles membrane after exocytosis [136].

The modulation performed by $\alpha$ Syn on synaptic vesicle recycling may also be related to a further role of the protein in the regulation of fatty acid metabolism [141-143]. $\alpha$ Syn regulates the overall level of polyunsaturated fatty acids and modulates the activity of enzymes, such as acyl-CoA synthetase, which are critical in the fatty acid re-acylation pathway [144,145].

Kamp and Beyer in their work entered more in detail and, using electron spin resonance (ESR) spectroscopy, showed that binding of $\alpha$ Syn to cholesterol- and sphingomyelin-containing vesicles could help in their stabilization, protecting them from premature fusion [146]. Dikiy and Eliezer presented a model in which $\alpha$ Syn acts as a bridge with its $\mathrm{N}$-terminal region bound to the plasma membrane and its C-terminal domain bound to docked or budding vesicles [147]. Membrane interactions have also been implicated in $\alpha$ Syn aggregation. In particular, Lee and collaborators demonstrated that, when recombinant $\alpha$ Syn was added to brain membranes, the rate of aggregation of the fibrillization rate of the protein was increased [148].

\section{Extracellular $\alpha$ Syn}

Even if $\alpha$ Syn has been considered exclusively an intracellular protein, recently, this idea was challenged by the discovery of $\alpha$ Syn in the cerebrospinal fluid and blood in both normal and PD subjects $[149,150]$. The data collected so far did not give consistent results to address the question of whether the level of extracellular $\alpha$ Syn might be considered a reliable biomarker for $\alpha$ Syn-pathology. $\alpha$ Syn levels were reported to be significantly increased in patients affected by PD and multiple system atrophy [151], while in a different study, $\alpha$ Syn extracellular level appeared lower in PD-patients than in control subjects [152]. One 
interpretation of PD etiopathogenesis seemed to rely on a causative agent transmitted via retrograde and transneuronal transport to the susceptible brain regions, from enteric nerves, to lower brain stem nuclei, then to the midbrain and, finally, to cortical areas [153,154]. Increasing evidence supports the idea that $\alpha$ Syn might actually act as the pathogen responsible for the spreading of neurodegeneration. The mechanism of $\alpha$ Syn secretion from cells remains largely unknown, and the more interesting question is how endogenous $\alpha$ Syn is released in the extracellular space.

\section{1. $\alpha$ Syn Release}

To assess how $\alpha$ Syn is released from neurons, Lee et al. overexpressed human $\alpha$ Syn in neuroblastoma cells and in rat primary cortical neurons using an adenoviral vector. They demonstrated the presence of $\alpha$ Syn in the culture medium after two hours and an accumulation over time, suggesting a process of constitutive release from cells. To determine if $\alpha$ Syn release is mediated by exocytosis, they used incubation at low temperature, a blocker of vesicular exocytosis. They found that low temperature reduces the secretion of the protein, suggesting that $\alpha$ Syn is released from the cells by exocytosis in a stimulation-independent manner. Moreover, they used brefeldin A (BFA), an inhibitor of the classical ER-Golgi pathway [155,156], showing that BFA does not alter the release of $\alpha$ Syn, which thus appears to be independent of the ER-Golgi pathway. Furthermore, they demonstrated the presence of $\alpha$ Syn in the lumen of the vesicles and that aggregation of $\alpha$ Syn is favored in vesicle lumen [25]. The ER-Golgi pathway for secretion seems to be involved in others regions of the nervous system. In fact, Paillusson et al., working on a primary culture derived from the enteric nervous system (ENS), showed a level of secreted $\alpha$ Syn similar to the one present in other biological fluids [157]. The treatment of this primary culture of ENS with BFA drastically reduces the secretion of $\alpha$ Syn, suggesting that in the enteric neurons, the conventional pathway plays a central role [158]. Emmanouilidou et al. demonstrated that $\alpha$ Syn is physiologically secreted, associated with membrane vesicles that are similar in size, morphology and protein composition to exosomes. Moreover, using $\mathrm{Ca}^{2+}$ ionophores/chelators, they found that $\alpha \mathrm{Syn}$ secretion is affected by intracellular calcium concentration [159]. Upon mitochondrial or proteasomal inhibition, neurons were found more prone to release both monomeric and aggregated $\alpha$ Syn, arguing in favor of the possibility that $\alpha$ Syn is secreted upon defects in its folding or processing, due to conditions of cell stress [25]. To better understand the pathway involved in $\alpha$ Syn secretion, Hasegawa et al. [160] analyzed the multivesicular bodies (MVBs). MVBs are endocytic organelles with two destinations: they are responsible for the sequestration of proteins that are condemned to lysosomal degradation, and they undergo exocytic fusion with the plasma membrane, which leads to the release of intraluminal vesicles into the extracellular environment [161]. Vacuolar protein sorting 4 (VPS4) is a key component of the MBV exocytic pathway [162]. Using a dominant negative VPS4A in $\alpha$ Syn-expressing HEK293T and SH-SY5Y, Hasegawa et al. showed an increase in extracellular $\alpha$ Syn, suggesting that a perturbation in MVB-exosome genesis affects the process of $\alpha$ Syn release [160].

\section{2. $\alpha$ Syn Internalization}

The question of how extracellular $\alpha$ Syn in both the monomeric and oligomeric form contributes to neuronal toxicity in PD has been the subject of intensive research. Extracellular proteolytic enzymes, as matrix metalloproteases, were shown to degrade $\alpha$ Syn with the production of smaller protein species highly prone to aggregation [163]. Besides being extracellularly degraded, $\alpha$ Syn might be internalized 
by neurons [164], microglia [165,166] and astrocytes [167]. Many studies focused on the mechanism of $\alpha$ Syn uptake into cells. One hypothesis suggests the ability of $\alpha$ Syn oligomers to form pentameric pore-like structures in cell membranes that increase intracellular calcium, leading to oxidative stress, lysosomal leakage and mitochondrial dysfunction, resulting in cell vulnerability and neurodegeneration [168]. Feng et al. used a dopaminergic-like cell model with regulated $\alpha$ Syn expression, reporting an increase in membrane permeability and conductance due to pore formation. More importantly, they show for the first time that the extracellular application of an anti- $\alpha$ Syn antibody reverts the effects on membrane permeability, suggesting an $\alpha$ Syn interaction with the outer surface of the cell membrane [126]. Danzer et al. entered more in detail about $\alpha$ Syn species and showed that different aggregation conditions produce heterogeneous populations of $\alpha$ Syn oligomers, which can be differentiated on the basis of their biophysical properties and cellular effects. SH-SY5Y cells treated with Type A oligomers induced an increased membrane permeability and triggered cell death, while Type B and C oligomers were able to enter cells directly and to seed intracellular $\alpha$ Syn aggregation [125]. Moreover, they demonstrated that the Type $\mathrm{C}$ oligomers are capable of inducing transmembrane $\alpha$ Syn seeding in a dose- and time-dependent manner, also in cortical primary neurons [169]. Lee et al. showed that the internalization of $\alpha$ Syn aggregates in cells is inhibited by the expression of a dominant-negative dynamin-1 or by low temperature, indicating that the internalization depends on endocytosis. More in depth, they demonstrated that this form of endocytosis of $\alpha$ Syn aggregates depends on an unknown membrane surface receptor [170]. Many authors suggest that monomeric $\alpha$ Syn internalization occurs very rapidly via a mechanism distinct from normal endocytosis. In fact, they show that the protein is detectable in the cytoplasm of the cells after five minutes of incubation. Moreover, the import of $\alpha$ Syn is not affected by temperature or the inhibitor of endocytosis, suggesting a direct translocation across the plasma membrane $[167,170]$. These distinctions were partially contradicted by the very recent finding that neuron-to-neuron transfer of monomeric, oligomeric, as well as fibrillar $\alpha$ Syn relied on endocytic processes, as demonstrated by experiments performed with selective endocytosis inhibitors, both in vitro and in vivo [171]. Sung et al. suggest that $\alpha$ Syn alone is not able to traverse the membrane and identified a possible carrier with a $60-\mathrm{kDa}$ molecular size, which appears to bind to $\alpha$ Syn in a specific way [164]. Membrane trafficking plays a central role in the maintenance of cell organization and organelle homeostasis and is necessary for intercellular signaling [172]. Chai et al. in their work used transferrin-mediated iron uptake [173] to study alteration in intracellular trafficking induced by $\alpha$ Syn oligomers. They show that after internalization of the oligomers, the rate of transferrin receptor recycling is increased, and consequently, the surface expression of the receptor is modified. [174]. It has been suggested that microglial inflammation augments the progression of PD [175]. Using different primary mesencephalic cultures, Zhang et al. demonstrated that $\alpha$ Syn aggregates can be phagocytized into microglia cells. Subsequent activation of NADPH oxidase plays a central role in microglial activation of the inflammation process, leading to neurotoxicity [165]. Similar results were obtained by performing experiments with primary astrocytic cultures or astrocytoma cell lines, which exhibited the acquisition of a reactive phenotype upon incubation with extracellular $\alpha$ Syn $[176,177]$. The toxic phenotype observed in neurons seems to derive from the non-cell autonomous interaction between neurons and glia, mediated by $\alpha$ Syn, which may lead to chronic inflammation. It has to be reminded that both PD-affected patients and animal models show signs of chronic inflammation. Since $\alpha$ Syn seems to be implicated in exocytosis [20] and in the recycling of the synaptic vesicles [21], accumulation of $\alpha$ Syn monomers as a result of constant internalization could also 
alter the physiological state of membrane trafficking and synaptic transmission. The model in Figure 2 depicts various possible routes of release and internalization of $\alpha$ Syn.

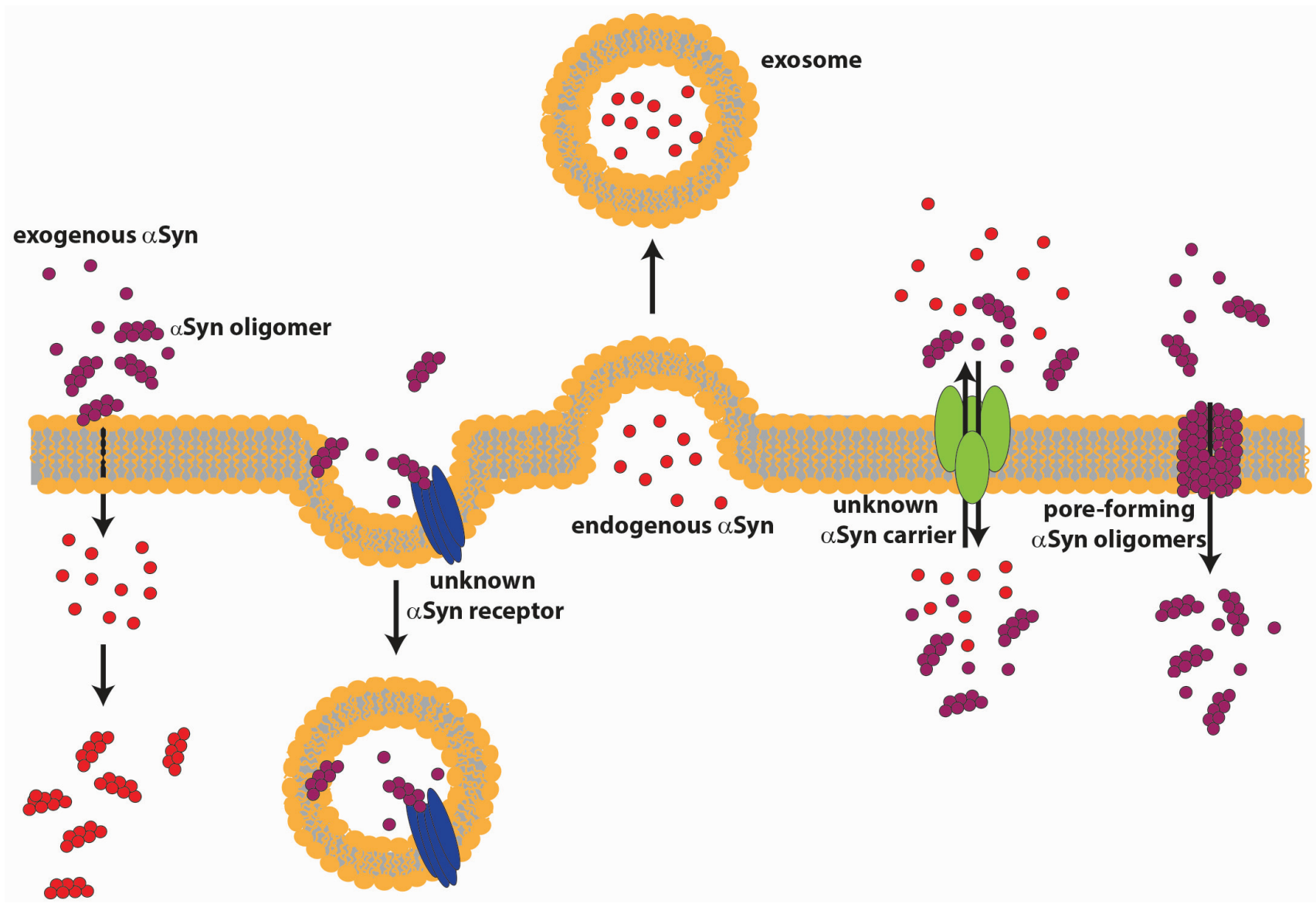

Figure 2. Mechanisms of $\alpha$ Syn release and internalization. $\alpha$ Syn can be released from healthy neurons by conventional exocytosis of vesicles or MVB, or through exosomes, or can pass the membrane with the help of an unknown carrier. $\alpha$ Syn can enter neurons by internalization in vesicles, or through pores formed into the membrane by $\alpha$ Syn oligomers, or by direct translocation across the plasma membrane.

\subsection{Extracellular $\alpha$ Syn Action}

Some data sustained that $\alpha$ Syn, after being internalized, may also trigger the seeding of endogenous proteins, both in neuroblastoma cells and in primary cortical neurons [125,169]. Even though in earlier studies, aSyn-mediated seeding occurred only with the assistance of artificial techniques, as liposomes, [64,178], a more recent work showed that this process might occur even with only the presence of extracellular $\alpha$ Syn per se, either in its monomeric or polymerized structure [171]. A report showed the presence of $\alpha$ Syn-containing depositions in proliferating stem cells engrafted in the hippocampus of a PD-mouse model [179]. Finally, a recent study mimicked more closely the clinical situation for human patients, by grafting fetal dopaminergic neurons, at a postmitotic developmental stage, into the striatum of mice overexpressing human $\alpha$ Syn, showing the transfer of human Syn to grafted cells, where it seeded the assembly of soluble $\alpha$ Syn, thus forming toxic deposits [171]. Another study provided evidence for the transfer of $\alpha$ Syn from an intrastriatal inoculation to recipient cells, where it seeds the assembly of soluble 
$\alpha$ Syn, leading to Lewy pathology in a connectivity-dependent way, propagating along interneuronal circuits [180]. In a very recent work, injection of a non-amyloidogenic, a truncated form of $\alpha$ Syn, was shown to induce neuronal pathology, such as dystrophic neurites and astrogliosis, eight month after injection, indicating that pathological alterations cannot be attributed only to conformational-dependent templating events and pointing to the importance of a high dosage of soluble $\alpha$ Syn in the onset of the disease. Notably, besides the increase in $\alpha$ Syn expression due to duplication and triplication of the $\alpha$ Syn gene, any form of brain injury may promote the release of monomeric cellular $\alpha$ Syn; also, $\alpha$ Syn release could occur during neurodegeneration upon neuronal death [181].

In PD models of $\alpha$ Syn overexpression, dopaminergic neuron loss is preceded by degenerative changes in striatal axons and terminals, indicating that $\alpha$ Syn-induced pathology hits the axons and terminals first and suggesting that the cell bodies are involved by a dying back mechanism.

$\alpha$ Syn monomers and oligomers might also exert their effect directly from the extracellular space on pre- and post-synaptic terminals. Diogenes et al. showed that, in rat hippocampal slices, prolonged exposure to $\alpha$ Syn oligomers determines an increase of basal synaptic transmission dependent on N-methyl-D-aspartate (NMDA) receptor activation. Moreover, they showed that the increase in NMDA receptor activity triggers an enhanced contribution of GluR1-containg $\alpha$-amino-3-hydroxy-5-methyl-4-isoxazolepropionic acid (AMPA) receptor. In the long term, this non-physiological activity of AMPA receptors leads to impaired long-term potentiation (LTP) [182]. Melachroinou et al. used the application of naturally-secreted $\alpha$ Syn on rat cortical neurons and showed that extracellular $\alpha$ Syn can perturbs $\mathrm{Ca}^{2+}$ homeostasis with a mechanism that alters the fluidity property of the membrane [183]. Ronzitti and collaborators demonstrated that dysregulation of neurotransmitter release induced by monomeric extracellular $\alpha$ Syn depends on the activation of surface-exposed calcium channels. They provided evidence that extracellular $\alpha$ Syn, applied on rat cortical neurons or striatal slices, selectively activates N-type VOCCs, inducing neurotransmitter release. Moreover, they correlated the effect of $\alpha$ Syn with the reduction of membrane cholesterol and with the ensuing alteration in partitioning of N-type VOCCs, which move from raft to cholesterol-poor areas of the plasma membrane [184]. $\alpha$ Syn's role in the regulation of axonal transport of synaptic vesicles [185] and of synaptic vesicle mobilization at the terminal might be mediated by a specific binding with proteins belonging to or associated with microtubules and microfilaments. Syn may interact with the MT-binding domain of protein tau [186], MT-associated protein 1B (MAP1B) [187] and 2 (MAP2) [188]. aSyn and actin has been observed to partially co-localize in neuronal cell lines [189]. $\alpha$ Syn can also influence the cytoskeleton of cultured neurons when applied to the extracellular milieu. Using a biochemical approach, Alim et al. showed that $\alpha$ Syn binds to heterodimeric tubulin and may seed $\alpha$ Syn fibril formation, an interaction capability that is lost by the mutant forms of $\alpha$ Syn [190]. Liu and collaborators demonstrated that application of wt $\alpha$ Syn to cultured primary rat cortical neurons leads to microtubule assembly and neurite outgrowth. The A30P and the A53T mutant forms do not show the same effect [191]. Various studies indicated a strong relationship between $\alpha$ Syn and the microtubule-associated protein tau in the neurodegenerative process [192,193]. The major function of tau is the stabilization of microtubule dynamics necessary for neurite outgrowth, morphogenesis, axonal transport and physiological neuronal function [194]. Gassowska et al. suggest that the interaction of $\alpha$ Syn with tau, increasing phosphorylation of tau by GSK-3 $\beta$, leads to microtubule destabilization [195]. Bellani et al. showed that the interaction of $\alpha$ Syn with a surface-exposed glucose-related protein of $78 \mathrm{kDa}$ (GRP78) activates a signaling cascade that, acting on cofilin 1, affects the morphology and dynamics of the actin cytoskeleton. 
Downregulation of GRP78 abolishes the activity of exogenous $\alpha$ Syn, suggesting that it is the primary target of $\alpha$ Syn [196]. In the model in Figure 3 are shown the targets of extracellular $\alpha$ Syn acting from the extracellular space.

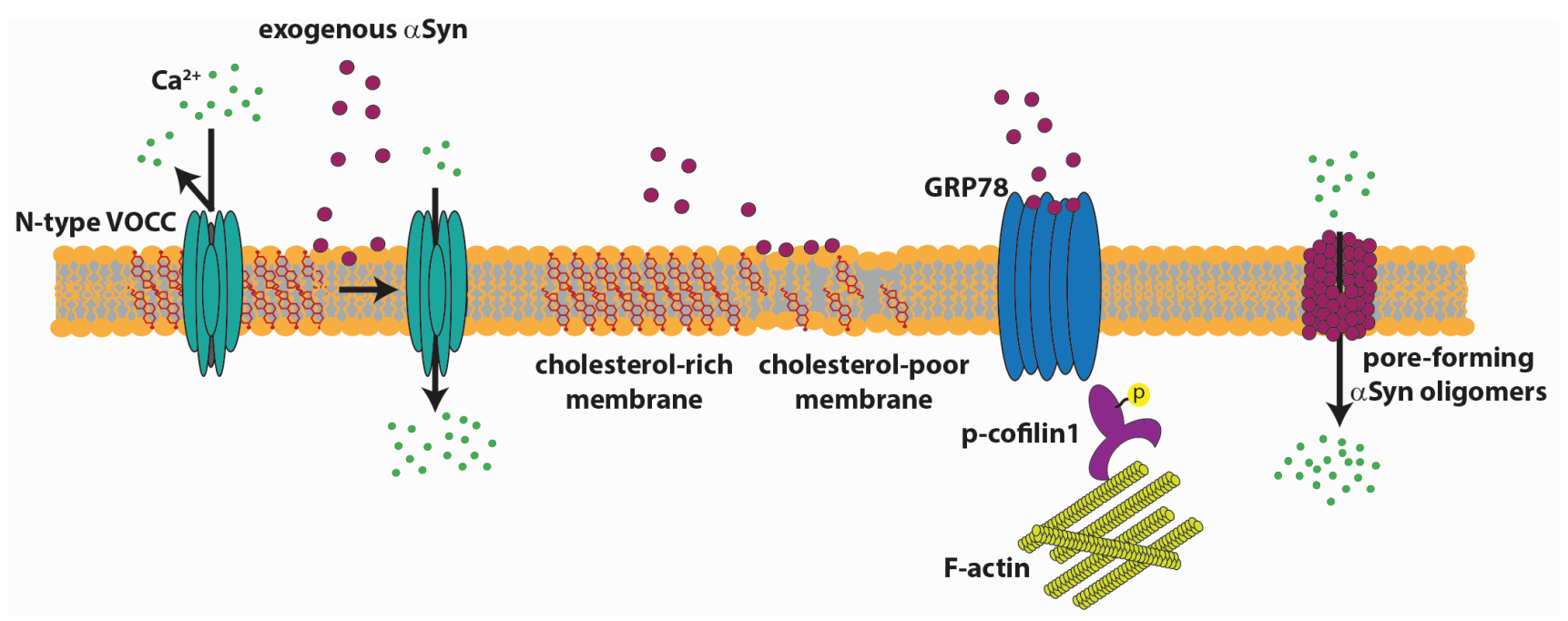

Figure 3. Targets of extracellular $\alpha$ Syn. Extracellular soluble $\alpha$ Syn induces an increase in calcium entry by acting on the fluidity of the membrane or by activating N-type calcium channels that shift to cholesterol-poor domains of the membrane. Extracellular soluble $\alpha$ Syn clusters GRP78 at the plasma membrane, with ensuing activation of a pathway that leads to cofilin 1 phosphorylation.

\section{Conclusions}

The studies reported here highlight the multitude of possible pathological effects of $\alpha$ Syn. This relevance of $\alpha$ Syn has stimulated the development of numerous animal models obtained with genetic approaches (deletion or overexpression of the SNCA gene) or chemical perturbation. Animal models have obvious limitations in representing the overall features of the pathology, in that very few of them recapitulate the characteristic signs of PD, i.e., consistent neuronal damage in the nigrostriatal pathway and the formation of Lewy bodies. However, they offer invaluable insight for the analysis of the specific mechanisms of PD pathogenesis.

Models alternative to mice have been used, either because they allow easier genetic manipulation and large-scale screening for the discovery of novel pathways involved in the pathology or, on the other side, because their neuronal circuits more closely resemble that of humans. Lakso et al. overexpressed both wt and A53T aSyn by injection into Caenorhabditis elegans and obtained neuronal and dendritic loss and motor deficits [197]. Transgenic Drosophila expressing wt, A30P or A53T $\alpha$ Syn replicate the features of human PD, with dopaminergic neuron loss, filamentous intraneuronal $\alpha$ Syn inclusions and locomotor dysfunction [198]. Yamada et al. used a recombinant adeno-associated viral vector system for human $\alpha$ Syn gene transfer to rat substantia nigra and observed approximately 50\% loss of dopaminergic neurons at 13 weeks after infection [199]. Overexpression of human $\alpha$ Syn in rats using a human BAC construct containing the entire SNCA sequence led to neurotoxic conversion of monomeric aSyn into insoluble aggregates in striatum, severe loss of dopaminergic integrity and a behavior phenotype similar to that in human PD [200]. Moreover rat lentiviral-based models of PD expressing A30P or A53T aSyn exhibit 
protein aggregates, selective loss of nigral dopaminergic neurons and $\alpha$-synucleinopathy [201]. Transgenic monkeys overexpressing wt or A53T $\alpha$ Syn developed motor impairments, $\alpha$ Syn-positive inclusions and dystrophic neurites, resembling the chronic and progressive characteristics of human PD [202].

In mice, the expression of wt and mutant forms of $\alpha$ Syn causes effects frequently observed in human PD. Van der Putten and collaborators showed that expression of wt and A53T $\alpha$ Syn in the nervous system of mice generated animals with neuronal $\alpha$-synucleinopathy, neuronal degeneration and motor defects [203]. Similarly, the overexpression of A30P $\alpha$ Syn led to motor dysfunction, reduced size of the dopamine (DA) storage pool, decreased locomotion and impaired motor coordination and balance [96,204].

Between all of the models, it appears that lentiviral injection for $\alpha$ Syn expression induces a more severe phenotype and dopaminergic neuronal death, possibly because of a lack of compensatory mechanisms, as might happen in transgenic animals. Thus, the construction of novel animal models with conditional expression of $\alpha \mathrm{Syn}$, as well as of other members of the synuclein family, regulated for time and localization of expression, may provide new insights into molecular mechanisms of the disorders related to $\alpha$ Syn.

\section{Acknowledgments}

We thank the Telethon Foundation for financial support.

\section{Author Contributions}

The authors equally contributed to the writing of this review.

\section{Conflicts of Interest}

The authors declare no conflict of interest.

\section{References}

1. Maroteaux, L.; Campanelli, J.T.; Scheller, R.H. Synuclein: A neuron-specific protein localized to the nucleus and presynaptic nerve terminal. J. Neurosci. 1988, 8, 2804-2815.

2. Spillantini, M.G.; Schmidt, M.L.; Lee, V.M.-Y.; Trojanowski, J.Q.; Jakes, R.; Goedert, M. $\alpha$-Synuclein in Lewy bodies. Nature 1997, 388, 839-840.

3. Shults, C.W. Lewy bodies. Proc. Natl. Acad. Sci. USA 2006, 103, 1661-1668.

4. Jensen, P.H.; Nielsen, M.S.; Jakes, R.; Dotti, C.G.; Goedert, M. Binding of $\alpha$-synuclein to brain vesicles is abolished by familial Parkinson's disease mutation. J. Biol. Chem. 1998, 273, 26292-26294.

5. Volles, M.J.; Lansbury, P.T. Relationships between the sequence of alpha-synuclein and its membrane affinity, fibrillization propensity, and yeast toxicity. J. Mol. Biol. 2007, 366, 1510-1522.

6. Uéda, K.; Fukushima, H.; Masliah, E.; Xia, Y.; Iwai, A.; Yoshimoto, M.; Otero, D.A.; Kondo, J.; Ihara, Y.; Saitoh, T. Molecular cloning of cDNA encoding an unrecognized component of amyloid in Alzheimer disease. Proc. Natl. Acad. Sci. USA 1993, 90, 11282-11286.

7. Han, H.; Weinreb, P.H.; Lansbury, P.T. The core Alzheimer's peptide NAC forms amyloid fibrils which seed and are seeded by beta-amyloid: Is NAC a common trigger or target in neurodegenerative disease? Chem. Biol. 1995, 2, 163-169. 
8. Alderson, T.R.; Markley, J.L. Biophysical characterization of $\alpha$-synuclein and its controversial structure. Intrinsically Disord. Proteins 2013, 1, e26255-1-e26255-22.

9. Nielsen, M.S.; Vorum, H.; Lindersson, E.; Jensen, P.H. $\mathrm{Ca}^{2+}$ binding to $\alpha$-synuclein regulates ligand binding and oligomerization. J. Biol. Chem. 2001, 276, 22680-22684.

10. Crowther, R.A.; Jakes, R.; Spillantini, M.G.; Goedert, M. Synthetic filaments assembled from C-terminally truncated alpha-synuclein. FEBS Lett. 1998, 436, 309-312.

11. Murray, I.V.J.; Giasson, B.I.; Quinn, S.M.; Koppaka, V.; Axelsen, P.H.; Ischiropoulos, H.; Trojanowski, J.Q.; Lee, V.M.-Y. Role of $\alpha$-synuclein carboxy-terminus on fibril formation in vitro. Biochemistry 2003, 42, 8530-8540.

12. Giasson, B.I.; Duda, J.E.; Murray, I.V.; Chen, Q.; Souza, J.M.; Hurtig, H.I.; Ischiropoulos, H.; Trojanowski, J.Q.; Lee, V.M. Oxidative damage linked to neurodegeneration by selective $\alpha$-synuclein nitration in synucleinopathy lesions. Science 2000, 290, 985-989.

13. Fujiwara, H.; Hasegawa, M.; Dohmae, N.; Kawashima, A.; Masliah, E.; Goldberg, M.S.; Shen, J.; Takio, K.; Iwatsubo, T. $\alpha$-Synuclein is phosphorylated in synucleinopathy lesions. Nat. Cell Biol. 2002, 4, 160-164.

14. Cookson, M.R. The biochemistry of Parkinson's disease. Annu. Rev. Biochem. 2005, 74, $29-52$.

15. Uversky, V.N. A protein-chameleon: Conformational plasticity of alpha-synuclein, a disordered protein involved in neurodegenerative disorders. J. Biomol. Struct. Dyn. 2003, 21, 211-234.

16. Uversky, V.N. Intrinsically disordered proteins from A to Z. Int. J. Biochem. Cell Biol. 2011, 43, 1090-1103.

17. Breydo, L.; Wu, J.W.; Uversky, V.N. $\alpha$-Synuclein misfolding and Parkinson's disease. Biochim. Biophys. Acta 2012, 1822, 261-285.

18. Uversky, V.N.; Li, J.; Fink, A.L. Evidence for a partially folded intermediate in $\alpha$-synuclein fibril formation. J. Biol. Chem. 2001, 276, 10737-10744.

19. Uversky, V.N.; Cooper, E.M.; Bower, K.S.; Li, J.; Fink, A.L. Accelerated $\alpha$-synuclein fibrillation in crowded milieu. FEBS Lett. 2002, 515, 99-103.

20. Chandra, S.; Gallardo, G.; Fernández-Chacón, R.; Schlüter, O.M.; Südhof, T.C. $\alpha$-Synuclein cooperates with CSP $\alpha$ in preventing neurodegeneration. Cell 2005, 123, 383-396.

21. Lykkebo, S.; Jensen, P.H. $\alpha$-Synuclein and presynaptic function. NeuroMol. Med. 2002, 2, 115-129.

22. Abeliovich, A.; Schmitz, Y.; Fariñas, I.; Choi-Lundberg, D.; Ho, W.-H.; Castillo, P.E.; Shinsky, N.; Verdugo, J.M.G.; Armanini, M.; Ryan, A.; et al. Mice lacking $\alpha$-synuclein display functional deficits in the nigrostriatal dopamine system. Neuron 2000, 25, 239-252.

23. Goedert, M. $\alpha$-Synuclein and neurodegenerative diseases. Nat. Rev. Neurosci. 2001, 2, 492-501.

24. Winner, B.; Jappelli, R.; Maji, S.K.; Desplats, P.A.; Boyer, L.; Aigner, S.; Hetzer, C.; Loher, T.; Vilar, M.; Campioni, S.; et al. In vivo demonstration that $\alpha$-synuclein oligomers are toxic. Proc. Natl. Acad. Sci. USA 2011, 108, 4194-4199.

25. Lee, H.-J.; Patel, S.; Lee, S.-J. Intravesicular localization and exocytosis of $\alpha$-synuclein and its aggregates. J. Neurosci. 2005, 25, 6016-6024.

26. Li, J.; Uversky, V.N.; Fink, A.L. Effect of familial Parkinson's disease point mutations A30P and A53T on the structural properties, aggregation, and fibrillation of human $\alpha$-synuclein. Biochemistry 2001, 40, 11604-11613. 
27. Uversky, V.N.; Lee, H.-J.; Li, J.; Fink, A.L.; Lee, S.-J. Stabilization of partially folded conformation during $\alpha$-synuclein oligomerization in both purified and cytosolic preparations. J. Biol. Chem. 2001, 276, 43495-43498.

28. Uversky, V.N.; Li, J.; Fink, A.L. Metal-triggered structural transformations, aggregation, and fibrillation of human $\alpha$-synuclein a possible molecular link between Parkinson's disease and heavy metal exposure. J. Biol. Chem. 2001, 276, 44284-44296.

29. Uversky, V.N.; Li, J.; Fink, A.L. Pesticides directly accelerate the rate of $\alpha$-synuclein fibril formation: A possible factor in Parkinson's disease. FEBS Lett. 2001, 500, 105-108.

30. Wood, S.J.; Wypych, J.; Steavenson, S.; Louis, J.-C.; Citron, M.; Biere, A.L. $\alpha$-Synuclein fibrillogenesis is nucleation-dependent implications for the pathogenesis of parkinson's disease. J. Biol. Chem. 1999, 274, 19509-19512.

31. Cheng, F.; Vivacqua, G.; Yu, S. The role of alpha-synuclein in neurotransmission and synaptic plasticity. J. Chem. Neuroanat. 2011, 42, 242-248.

32. Elkon, H.; Don, J.; Melamed, E.; Ziv, I.; Shirvan, A.; Offen, D. Mutant and wild-type $\alpha$-synuclein interact with mitochondrial cytochrome C oxidase. J. Mol. Neurosci. 2002, 18, 229-238.

33. Junn, E.; Mouradian, M.M. Human $\alpha$-synuclein over-expression increases intracellular reactive oxygen species levels and susceptibility to dopamine. Neurosci. Lett. 2002, 320, 146-150.

34. Volles, M.J.; Lee, S.-J.; Rochet, J.-C.; Shtilerman, M.D.; Ding, T.T.; Kessler, J.C.; Lansbury, P.T. Vesicle permeabilization by protofibrillar $\alpha$-synuclein: Implications for the pathogenesis and treatment of Parkinson's disease. Biochemistry 2001, 40, 7812-7819.

35. Volles, M.J.; Lansbury, P.T. Vesicle permeabilization by protofibrillar $\alpha$-synuclein is sensitive to Parkinson's disease-linked mutations and occurs by a pore-like mechanism. Biochemistry 2002, 41, 4595-4602.

36. Emmanouilidou, E.; Stefanis, L.; Vekrellis, K. Cell-produced $\alpha$-synuclein oligomers are targeted to, and impair, the 26S proteasome. Neurobiol. Aging 2010, 31, 953-968.

37. Polymeropoulos, M.H.; Lavedan, C.; Leroy, E.; Ide, S.E.; Dehejia, A.; Dutra, A.; Pike, B.; Root, H.; Rubenstein, J.; Boyer, R.; et al. Mutation in the $\alpha$-synuclein gene identified in families with Parkinson's disease. Science 1997, 276, 2045-2047.

38. Krüger, R.; Kuhn, W.; Müller, T.; Woitalla, D.; Graeber, M.; Kösel, S.; Przuntek, H.; Epplen, J.T.; Schols, L.; Riess, O. AlaSOPro mutation in the gene encoding $\alpha$-synuclein in Parkinson's disease. Nat. Genet. 1998, 18, 106-108.

39. Zarranz, J.J.; Alegre, J.; Gómez-Esteban, J.C.; Lezcano, E.; Ros, R.; Ampuero, I.; Vidal, L.; Hoenicka, J.; Rodriguez, O.; Atarés, B.; et al. The new mutation, E46K, of $\alpha$-synuclein causes parkinson and Lewy body dementia. Ann. Neurol. 2004, 55, 164-173.

40. Appel-Cresswell, S.; Vilarino-Guell, C.; Encarnacion, M.; Sherman, H.; Yu, I.; Shah, B.; Weir, D.; Thompson, C.; Szu-Tu, C.; Trinh, J.; et al. Alpha-synuclein p.H50Q, a novel pathogenic mutation for Parkinson's disease. Mov. Disord. 2013, 28, 811-813.

41. Kiely, A.P.; Asi, Y.T.; Kara, E.; Limousin, P.; Ling, H.; Lewis, P.; Proukakis, C.; Quinn, N.; Lees, A.J.; Hardy, J.; et al. $\alpha$-Synucleinopathy associated with G51D SNCA mutation: A link between Parkinson's disease and multiple system atrophy? Acta Neuropathol. 2013, 125, 753-769. 
42. Lesage, S.; Anheim, M.; Letournel, F.; Bousset, L.; Honoré, A.; Rozas, N.; Pieri, L.; Madiona, K.; Dürr, A.; Melki, R.; et al. G51D $\alpha$-synuclein mutation causes a novel parkinsonian-pyramidal syndrome. Ann. Neurol. 2013, 73, 459-471.

43. Proukakis, C.; Dudzik, C.G.; Brier, T.; MacKay, D.S.; Cooper, J.M.; Millhauser, G.L.; Houlden, H.; Schapira, A.H. A novel $\alpha$-synuclein missense mutation in Parkinson disease. Neurology 2013, 80, 1062-1064.

44. Spira, P.J.; Sharpe, D.M.; Halliday, G.; Cavanagh, J.; Nicholson, G.A. Clinical and pathological features of a Parkinsonian syndrome in a family with an Ala53Thr $\alpha$-synuclein mutation. Ann. Neurol. 2001, 49, 313-319.

45. Conway, K.A.; Harper, J.D.; Lansbury, P.T. Fibrils formed in vitro from $\alpha$-synuclein and two mutant forms linked to Parkinson's disease are typical amyloid. Biochem. 2000, 39, 2552-2563.

46. Rutherford, N.J.; Moore, B.D.; Golde, T.E.; Giasson, B.I. Divergent effects of the H50Q and G51D SNCA mutations on the aggregation of $\alpha$-synuclein. J. Neurochem. 2014, 131, 859-867.

47. Tanaka, Y.; Engelender, S.; Igarashi, S.; Rao, R.K.; Wanner, T.; Tanzi, R.E.; Sawa, A.; Dawson, V.L.; Dawson, T.M.; Ross, C.A. Inducible expression of mutant $\alpha$-synuclein decreases proteasome activity and increases sensitivity to mitochondria-dependent apoptosis. Hum. Mol. Genet. 2001, 10, 919-926.

48. Nonaka, T.; Hasegawa, M. A cellular model to monitor proteasome dysfunction by $\alpha$-synuclein. Biochem. 2009, 48, 8014-8022.

49. Ko, L.; Mehta, N.D.; Farrer, M.; Easson, C.; Hussey, J.; Yen, S.; Hardy, J.; Yen, S.-H.C. Sensitization of neuronal cells to oxidative stress with mutated human $\alpha$-synuclein. J. Neurochem. 2000, 75, 2546-2554.

50. Kanda, S.; Bishop, J.F.; Eglitis, M.A.; Yang, Y.; Mouradian, M.M. Enhanced vulnerability to oxidative stress by $\alpha$-synuclein mutations and C-terminal truncation. Neuroscience 2000, 97, $279-284$.

51. Tabrizi, S.J.; Orth, M.; Wilkinson, J.M.; Taanman, J.-W.; Warner, T.T.; Cooper, J.M.; Schapira, A.H.V. Expression of mutant $\alpha$-synuclein causes increased susceptibility to dopamine toxicity. Hum. Mol. Genet. 2000, 9, 2683-2689.

52. Singleton, A.B.; Farrer, M.; Johnson, J.; Singleton, A.; Hague, S.; Kachergus, J.; Hulihan, M.; Peuralinna, T.; Dutra, A.; Nussbaum, R.; et al. $\alpha$-Synuclein locus triplication causes Parkinson's disease. Science 2003, 302, 841.

53. Ross, O.A.; Braithwaite, A.T.; Skipper, L.M.; Kachergus, J.; Hulihan, M.M.; Middleton, F.A.; Nishioka, K.; Fuchs, J.; Gasser, T.; Maraganore, D.M.; et al. Genomic investigation of $\alpha$-synuclein multiplication and parkinsonism. Ann. Neurol. 2008, doi:10.1002/ana.21380.

54. Devine, M.J.; Ryten, M.; Vodicka, P.; Thomson, A.J.; Burdon, T.; Houlden, H.; Cavaleri, F.; Nagano, M.; Drummond, N.J.; Taanman, J.-W.; et al. Parkinson's disease induced pluripotent stem cells with triplication of the $\alpha$-synuclein locus. Nat. Commun. 2011, doi:10.1038/ncomms 1453.

55. Flierl, A.; Oliveira, L.M.A.; Falomir-Lockhart, L.J.; Mak, S.K.; Hesley, J.; Soldner, F.; Arndt-Jovin, D.J.; Jaenisch, R.; Langston, J.W.; Jovin, T.M.; et al. Higher vulnerability and stress sensitivity of neuronal precursor cells carrying an alpha-synuclein gene triplication. PLOS ONE 2014, doi:10.1371/journal.pone.0112413. 
56. Edwards, T.L.; Scott, W.K.; Almonte, C.; Burt, A.; Powell, E.H.; Beecham, G.W.; Wang, L.; Züchner, S.; Konidari, I.; Wang, G.; et al. Genome-wide association study confirms SNPs in SNCA and the MAPT region as common risk factors for Parkinson disease. Ann. Hum. Genet. 2010, 74, 97-109.

57. Simón-Sánchez, J.; Schulte, C.; Bras, J.M.; Sharma, M.; Gibbs, J.R.; Berg, D.; Paisan-Ruiz, C.; Lichtner, P.; Scholz, S.W.; Hernandez, D.G.; et al. Genome-wide association study reveals genetic risk underlying Parkinson's disease. Nat. Genet. 2009, 41, 1308-1312.

58. Chu, Y.; Kordower, J.H. Age-associated increases of $\alpha$-synuclein in monkeys and humans are associated with nigrostriatal dopamine depletion: Is this the target for Parkinson's disease? Neurobiol. Dis. 2007, 25, 134-149.

59. Uversky, V.N.; Yamin, G.; Souillac, P.O.; Goers, J.; Glaser, C.B.; Fink, A.L. Methionine oxidation inhibits fibrillation of human alpha-synuclein in vitro. FEBS Lett. 2002, 517, 239-244.

60. Hokenson, M.J.; Uversky, V.N.; Goers, J.; Yamin, G.; Munishkina, L.A.; Fink, A.L. Role of individual methionines in the fibrillation of methionine-oxidized alpha-synuclein. Biochemistry 2004, 43, 4621-4633.

61. Mishizen-Eberz, A.J.; Guttmann, R.P.; Giasson, B.I.; Day, G.A.; Hodara, R.; Ischiropoulos, H.; Lee, V.M.-Y.; Trojanowski, J.Q.; Lynch, D.R. Distinct cleavage patterns of normal and pathologic forms of alpha-synuclein by calpain I in vitro. J. Neurochem. 2003, 86, 836-847.

62. Okochi, M.; Walter, J.; Koyama, A.; Nakajo, S.; Baba, M.; Iwatsubo, T.; Meijer, L.; Kahle, P.J.; Haass, C. Constitutive phosphorylation of the Parkinson's disease associated $\alpha$-synuclein. J. Biol. Chem. 2000, 275, 390-397.

63. Pronin, A.N.; Morris, A.J.; Surguchov, A.; Benovic, J.L. Synucleins are a novel class of substrates for G protein-coupled receptor kinases. J. Biol. Chem. 2000, 275, 26515-26522.

64. Waxman, E.A.; Giasson, B.I. Characterization of kinases involved in the phosphorylation of aggregated $\alpha$-synuclein. J. Neurosci. Res. 2011, 89, 231-247.

65. Chen, L.; Feany, M.B. $\alpha$-Synuclein phosphorylation controls neurotoxicity and inclusion formation in a Drosophila model of Parkinson disease. Nat. Neurosci. 2005, 8, 657-663.

66. Visanji, N.P.; Wislet-Gendebien, S.; Oschipok, L.W.; Zhang, G.; Aubert, I.; Fraser, P.E.; Tandon, A. Effect of Ser-129 phosphorylation on interaction of $\alpha$-synuclein with synaptic and cellular membranes. J. Biol. Chem. 2011, 286, 35863-35873.

67. Paleologou, K.E.; Oueslati, A.; Shakked, G.; Rospigliosi, C.C.; Kim, H.-Y.; Lamberto, G.R.; Fernandez, C.O.; Schmid, A.; Chegini, F.; Gai, W.P.; et al. Phosphorylation at S87 is enhanced in synucleinopathies, inhibits $\alpha$-synuclein oligomerization, and influences synuclein-membrane interactions. J. Neurosci. 2010, 30, 3184-3198.

68. Hasegawa, M.; Fujiwara, H.; Nonaka, T.; Wakabayashi, K.; Takahashi, H.; Lee, V.M.-Y.; Trojanowski, J.Q.; Mann, D.; Iwatsubo, T. Phosphorylated alpha-synuclein is ubiquitinated in alpha-synucleinopathy lesions. J. Biol. Chem. 2002, 277, 49071-49076.

69. Sadowski, M.; Sarcevic, B. Mechanisms of mono- and poly-ubiquitination: Ubiquitination specificity depends on compatibility between the E2 catalytic core and amino acid residues proximal to the lysine. Cell Div. 2010, doi:10.1186/1747-1028-5-19.

70. Nonaka, T.; Iwatsubo, T.; Hasegawa, M. Ubiquitination of $\alpha$-synuclein. Biochem. 2005, 44, 361-368. 
71. Steffan, J.S.; Agrawal, N.; Pallos, J.; Rockabrand, E.; Trotman, L.C.; Slepko, N.; Illes, K.; Lukacsovich, T.; Zhu, Y.-Z.; Cattaneo, E.; et al. SUMO modification of huntingtin and Huntington's disease pathology. Science 2004, 304, 100-104.

72. Krumova, P.; Meulmeester, E.; Garrido, M.; Tirard, M.; Hsiao, H.-H.; Bossis, G.; Urlaub, H.; Zweckstetter, M.; Kügler, S.; Melchior, F.; et al. Sumoylation inhibits $\alpha$-synuclein aggregation and toxicity. J. Cell Biol. 2011, 194, 49-60.

73. Kunadt, M.; Eckermann, K.; Stuendl, A.; Gong, J.; Russo, B.; Strauss, K.; Rai, S.; Kügler, S.; Lockhart, L.F.; Schwalbe, M.; et al. Extracellular vesicle sorting of $\alpha$-synuclein is regulated by sumoylation. Acta Neuropathol. 2015, 129, 695-713.

74. Jakes, R.; Spillantini, M.G.; Goedert, M. Identification of two distinct synucleins from human brain. FEBS Lett. 1994, 345, 27-32.

75. McLean, P.J.; Ribich, S.; Hyman, B.T. Subcellular localization of alpha-synuclein in primary neuronal cultures: Effect of missense mutations. J. Neural Transm. Suppl. 2000, 7, 53-63.

76. Zhong, S.; Luo, X.; Chen, X.; Cai, Q.; Liu, J.; Chen, X.; Yao, Z. Expression and subcellular location of $\alpha$-synuclein during mouse-embryonic development. Cell. Mol. Neurobiol. 2009, 30, 469-482.

77. Mori, F.; Tanji, K.; Yoshimoto, M.; Takahashi, H.; Wakabayashi, K. Immunohistochemical comparison of alpha- and beta-synuclein in adult rat central nervous system. Brain Res. 2002, 941, $118-126$.

78. Vivacqua, G.; Casini, A.; Vaccaro, R.; Fornai, F.; Yu, S.; D’Este, L. Different sub-cellular localization of alpha-synuclein in the C57BL $\backslash 6 \mathrm{~J}$ mouse's central nervous system by two novel monoclonal antibodies. J. Chem. Neuroanat. 2011, 41, 97-110.

79. Richter-Landsberg, C.; Gorath, M.; Trojanowski, J.Q.; Lee, V.M. Alpha-synuclein is developmentally expressed in cultured rat brain oligodendrocytes. J. Neurosci. Res. 2000, 62, 9-14.

80. Wakabayashi, K.; Hayashi, S.; Yoshimoto, M.; Kudo, H.; Takahashi, H. NACP/ $\alpha$-synuclein-positive filamentous inclusions in astrocytes and oligodendrocytes of Parkinson's disease brains. Acta Neuropathol. 2000, 99, 14-20.

81. Tanji, K.; Mori, F.; Imaizumi, T.; Yoshida, H.; Matsumiya, T.; Tamo, W.; Yoshimoto, M.; Odagiri, H.; Sasaki, M.; Takahashi, H.; Satoh, K.; Wakabayashi, K. Upregulation of alpha-synuclein by lipopolysaccharide and interleukin-1 in human macrophages. Pathol. Int. 2002, 52, 572-577.

82. Tamo, W.; Imaizumi, T.; Tanji, K.; Yoshida, H.; Mori, F.; Yoshimoto, M.; Takahashi, H.; Fukuda, I.; Wakabayashi, K.; Satoh, K. Expression of $\alpha$-synuclein, the precursor of non-amyloid $\beta$ component of Alzheimer's disease amyloid, in human cerebral blood vessels. Neurosci. Lett. 2002, 326, 5-8.

83. Hashimoto, M.; Yoshimoto, M.; Sisk, A.; Hsu, L.J.; Sundsmo, M.; Kittel, A.; Saitoh, T.; Miller, A.; Masliah, E. NACP, a synaptic protein involved in Alzheimer's disease, is differentially regulated during megakaryocyte differentiation. Biochem. Biophys. Res. Commun. 1997, 237, 611-616.

84. Goers, J.; Manning-Bog, A.B.; McCormack, A.L.; Millett, I.S.; Doniach, S.; di Monte, D.A.; Uversky, V.N.; Fink, A.L. Nuclear localization of $\alpha$-synuclein and its interaction with histones. Biochemistry 2003, 42, 8465-8471.

85. Yu, S.; Li, X.; Liu, G.; Han, J.; Zhang, C.; Li, Y.; Xu, S.; Liu, C.; Gao, Y.; Yang, H.; et al. Extensive nuclear localization of alpha-synuclein in normal rat brain neurons revealed by a novel monoclonal antibody. Neuroscience 2007, 145, 539-555. 
86. Kahle, P.J.; Neumann, M.; Ozmen, L.; Müller, V.; Jacobsen, H.; Schindzielorz, A.; Okochi, M.; Leimer, U.; van der Putten, H.; Probst, A.; et al. Subcellular localization of wild-type and Parkinson's disease-associated mutant $\alpha$-synuclein in human and transgenic mouse brain. J. Neurosci. 2000, 20, 6365-6373.

87. Hsu, L.J.; Mallory, M.; Xia, Y.; Veinbergs, I.; Hashimoto, M.; Yoshimoto, M.; Thal, L.J.; Saitoh, T.; Masliah, E. Expression pattern of synucleins (non-Abeta component of Alzheimer's disease amyloid precursor protein/ $\alpha$-synuclein) during murine brain development. J. Neurochem. 1998, 71, 338-344.

88. Iwai, A.; Masliah, E.; Yoshimoto, M.; Ge, N.; Flanagan, L.; de Silva, H.A.; Kittel, A.; Saitoh, T. The precursor protein of non-A beta component of Alzheimer's disease amyloid is a presynaptic protein of the central nervous system. Neuron 1995, 14, 467-475.

89. Davidson, W.S.; Jonas, A.; Clayton, D.F.; George, J.M. Stabilization of $\alpha$-synuclein secondary structure upon binding to synthetic membranes. J. Biol. Chem. 1998, 273, 9443-9449.

90. Clayton, D.F.; George, J.M. Synucleins in synaptic plasticity and neurodegenerative disorders. J. Neurosci. Res. 1999, 58, 120-129.

91. George, J.M.; Jin, H.; Woods, W.S.; Clayton, D.F. Characterization of a novel protein regulated during the critical period for song learning in the zebra finch. Neuron 1995, 15, 361-372.

92. Hartman, V.N.; Miller, M.A.; Clayton, D.F.; Liu, W.C.; Kroodsma, D.E.; Brenowitz, E.A. Testosterone regulates $\alpha$-synuclein mRNA in the avian song system. Neuroreport 2001, 12, 943-946.

93. Snead, D.; Eliezer, D. $\alpha$-Synuclein function and dysfunction on cellular membranes. Exp. Neurobiol. 2014, 23, 292-313.

94. Murphy, D.D.; Rueter, S.M.; Trojanowski, J.Q.; Lee, V.M.-Y. Synucleins are developmentally expressed, and $\alpha$-synuclein regulates the size of the presynaptic vesicular pool in primary hippocampal neurons. J. Neurosci. 2000, 20, 3214-3220.

95. Yavich, L.; Tanila, H.; Vepsäläinen, S.; Jäkälä, P. Role of alpha-synuclein in presynaptic dopamine recruitment. J. Neurosci. 2004, 24, 11165-11170.

96. Yavich, L.; Oksman, M.; Tanila, H.; Kerokoski, P.; Hiltunen, M.; van Groen, T.; Puoliväli, J.; Männistö, P.T.; García-Horsman, A.; MacDonald, E.; et al. Locomotor activity and evoked dopamine release are reduced in mice overexpressing A30P-mutated human $\alpha$-synuclein. Neurobiol. Dis. 2005, 20, 303-313.

97. Yavich, L.; Jäkälä, P.; Tanila, H. Abnormal compartmentalization of norepinephrine in mouse dentate gyrus in $\alpha$-synuclein knockout and A30P transgenic mice. J. Neurochem. 2006, 99, 724-732.

98. Gureviciene, I.; Gurevicius, K.; Tanila, H. Role of $\alpha$-synuclein in synaptic glutamate release. Neurobiol. Dis. 2007, 28, 83-89.

99. Larsen, K.E.; Schmitz, Y.; Troyer, M.D.; Mosharov, E.; Dietrich, P.; Quazi, A.Z.; Savalle, M.; Nemani, V.; Chaudhry, F.A.; Edwards, R.H.; et al. $\alpha$-Synuclein overexpression in PC12 and chromaffin cells impairs catecholamine release by interfering with a late step in exocytosis. $J$. Neurosci. 2006, 26, 11915-11922.

100. Nemani, V.M.; Lu, W.; Berge, V.; Nakamura, K.; Onoa, B.; Lee, M.K.; Chaudhry, F.A.; Nicoll, R.A.; Edwards, R.H. Increased expression of $\alpha$-synuclein reduces neurotransmitter release by inhibiting synaptic vesicle reclustering after endocytosis. Neuron 2010, 65, 66-79. 
101. Cabin, D.E.; Shimazu, K.; Murphy, D.; Cole, N.B.; Gottschalk, W.; McIlwain, K.L.; Orrison, B.; Chen, A.; Ellis, C.E.; Paylor, R.; et al. Synaptic vesicle depletion correlates with attenuated synaptic responses to prolonged repetitive stimulation in mice lacking alpha-synuclein. J. Neurosci. 2002, 22, 8797-8807.

102. Chandra, S.; Fornai, F.; Kwon, H.-B.; Yazdani, U.; Atasoy, D.; Liu, X.; Hammer, R.E.; Battaglia, G.; German, D.C.; Castillo, P.E.; et al. Double-knockout mice for alpha- and beta-synucleins: Effect on synaptic functions. Proc. Natl. Acad. Sci. USA 2004, 101, 14966-14971.

103. Burre, J.; Sharma, M.; Tsetsenis, T.; Buchman, V.; Etherton, M.; Sudhof, T.C. $\alpha$-Synuclein promotes SNARE-complex assembly in vivo and in vitro. Science 2010, 329, 1663-1667.

104. Greten-Harrison, B.; Polydoro, M.; Morimoto-Tomita, M.; Diao, L.; Williams, A.M.; Nie, E.H.; Makani, S.; Tian, N.; Castillo, P.E.; Buchman, V.L.; et al. $\alpha \beta \gamma$-Synuclein triple knockout mice reveal age-dependent neuronal dysfunction. Proc. Natl. Acad. Sci. USA 2010, 107, 19573-19578.

105. Liu, S.; Ninan, I.; Antonova, I.; Battaglia, F.; Trinchese, F.; Narasanna, A.; Kolodilov, N.; Dauer, W.; Hawkins, R.D.; Arancio, O. $\alpha$-Synuclein produces a long-lasting increase in neurotransmitter release. EMBO J. 2004, 23, 4506-4516.

106. Martín, E.D.; González-García, C.; Milán, M.; Fariñas, I.; Ceña, V. Stressor-related impairment of synaptic transmission in hippocampal slices from alpha-synuclein knockout mice. Eur. J. Neurosci. 2004, 20, 3085-3091.

107. Lundblad, M.; Decressac, M.; Mattsson, B.; Björklund, A. Impaired neurotransmission caused by overexpression of $\alpha$-synuclein in nigral dopamine neurons. Proc. Natl. Acad. Sci. USA 2012, 109, 3213-3219.

108. Ahn, B.-H.; Rhim, H.; Kim, S.Y.; Sung, Y.-M.; Lee, M.-Y.; Choi, J.-Y.; Wolozin, B.; Chang, J.-S.; Lee, Y.H.; Kwon, T.K.; et al. $\alpha$-Synuclein interacts with phospholipase D isozymes and inhibits pervanadate-induced phospholipase D activation in human embryonic kidney-293 Cells. J. Biol. Chem. 2002, 277, 12334-12342.

109. Cockcroft, S. Signalling roles of mammalian phospholipase D1 and D2. Cell. Mol. Life Sci. 2001, $58,1674-1687$.

110. Jenco, J.M.; Rawlingson, A.; Daniels, B.; Morris, A.J. Regulation of phospholipase D2: Selective inhibition of mammalian phospholipase D isoenzymes by $\alpha$ - and $\beta$-synucleins. Biochem. 1998, 37 , 4901-4909.

111. Bellani, S.; Sousa, V.L.; Ronzitti, G.; Valtorta, F.; Meldolesi, J.; Chieregatti, E. The regulation of synaptic function by $\alpha$-synuclein. Commun. Integr. Biol. 2010, 3, 106-109.

112. Sousa, V.L.; Bellani, S.; Giannandrea, M.; Yousuf, M.; Valtorta, F.; Meldolesi, J.; Chieregatti, E. $\alpha$-Synuclein and its A30P mutant affect actin cytoskeletal structure and dynamics. Mol. Biol. Cell 2009, 20, 3725-3739.

113. Berridge, M.J.; Bootman, M.D.; Roderick, H.L. Calcium signalling: Dynamics, homeostasis and remodelling. Nat. Rev. Mol. Cell Biol. 2003, 4, 517-529.

114. Patel, S.; Docampo, R. Acidic calcium stores open for business: Expanding the potential for intracellular $\mathrm{Ca}^{2+}$ signaling. Trends Cell Biol. 2010, 20, 277-286.

115. Burgoyne, R.D. Neuronal calcium sensor proteins: Generating diversity in neuronal $\mathrm{Ca}^{2+}$ signalling. Nat. Rev. Neurosci. 2007, 8, 182-193. 
116. Thayer, S.A.; Usachev, Y.M.; Pottorf, W.J. Modulating $\mathrm{Ca}^{2+}$ clearance from neurons. Front. Biosci. J. Virtual Libr. 2002, 7, d1255-1279.

117. Zündorf, G.; Reiser, G. Calcium dysregulation and homeostasis of neural calcium in the molecular mechanisms of neurodegenerative diseases provide multiple targets for neuroprotection. Antioxid. Redox Signal. 2011, 14, 1275-1288.

118. Damier, P.; Hirsch, E.C.; Agid, Y.; Graybiel, A.M. The substantia nigra of the human brain. I. Nigrosomes and the nigral matrix, a compartmental organization based on calbindin $\mathrm{D}(28 \mathrm{~K})$ immunohistochemistry. Brain J. Neurol. 1999, 122, 1421-1436.

119. Kim, B.G.; Shin, D.H.; Jeon, G.S.; Seo, J.H.; Kim, Y.W.; Jeon, B.S.; Cho, S.S. Relative sparing of calretinin containing neurons in the substantia nigra of 6-OHDA treated rat parkinsonian model. Brain Res. 2000, 855, 162-165.

120. Soós, J.; Engelhardt, J.I.; Siklós, L.; Havas, L.; Majtényi, K. The expression of PARP, NF-кB and parvalbumin is increased in Parkinson disease. Neuroreport 2004, 15, 1715-1718.

121. Liang, C.L.; Sinton, C.M.; Sonsalla, P.K.; German, D.C. Midbrain dopaminergic neurons in the mouse that contain calbindin-D28k exhibit reduced vulnerability to MPTP-induced neurodegeneration. Neuroregeneration 1996, 5, 313-318.

122. Surmeier, D.J.; Guzman, J.N.; Sanchez-Padilla, J. Calcium, cellular aging, and selective neuronal vulnerability in Parkinson's disease. Cell Calcium 2010, 47, 175-182.

123. Adamczyk, A.; Strosznajder, J.B. $\alpha$-Synuclein potentiates $\mathrm{Ca}^{2+}$ influx through voltage-dependent $\mathrm{Ca}^{2+}$ channels. NeuroReport 2006, 17, 1883-1886.

124. Tamamizu-Kato, S.; Kosaraju, M.G.; Kato, H.; Raussens, V.; Ruysschaert, J.-M.; Narayanaswami, V. Calcium-triggered membrane interaction of the alpha-synuclein acidic tail. Biochemistry 2006, 45, 10947-10956.

125. Danzer, K.M.; Haasen, D.; Karow, A.R.; Moussaud, S.; Habeck, M.; Giese, A.; Kretzschmar, H.; Hengerer, B.; Kostka, M. Different species of $\alpha$-synuclein oligomers induce calcium influx and seeding. J. Neurosci. 2007, 27, 9220-9232.

126. Feng, L.R.; Federoff, H.J.; Vicini, S.; Maguire-Zeiss, K.A. $\alpha$-Synuclein mediates alterations in membrane conductance: A potential role for $\alpha$-synuclein oligomers in cell vulnerability. Eur. $J$. Neurosci. 2010, 32, 10-17.

127. Lashuel, H.A.; Petre, B.M.; Wall, J.; Simon, M.; Nowak, R.J.; Walz, T.; Lansbury, P.T. $\alpha-$ Synuclein, especially the Parkinson's disease-associated mutants, forms pore-like annular and tubular protofibrils. J. Mol. Biol. 2002, 322, 1089-1102.

128. Furukawa, K.; Matsuzaki-Kobayashi, M.; Hasegawa, T.; Kikuchi, A.; Sugeno, N.; Itoyama, Y.; Wang, Y.; Yao, P.J.; Bushlin, I.; Takeda, A. Plasma membrane ion permeability induced by mutant $\alpha$-synuclein contributes to the degeneration of neural cells. J. Neurochem. 2006, 97, 1071-1077.

129. Hettiarachchi, N.T.; Parker, A.; Dallas, M.L.; Pennington, K.; Hung, C.-C.; Pearson, H.A.; Boyle, J.P.; Robinson, P.; Peers, C. $\alpha$-Synuclein modulation of $\mathrm{Ca}^{2+}$ signaling in human neuroblastoma (SH-SY5Y) cells. J. Neurochem. 2009, 111, 1192-1201.

130. Martin, Z.S.; Neugebauer, V.; Dineley, K.T.; Kayed, R.; Zhang, W.; Reese, L.C.; Taglialatela, G. Alpha synuclein oligomers oppose long-term potentiation and impair memory through a calcineurin-dependent mechanism: Relevance to human synucleopathic diseases. J. Neurochem. 2012, 120, 440-452. 
131. Eliezer, D.; Kutluay, E.; Bussell, R., Jr.; Browne, G. Conformational properties of $\alpha$-synuclein in its free and lipid-associated states. J. Mol. Biol. 2001, 307, 1061-1073.

132. Chandra, S.; Chen, X.; Rizo, J.; Jahn, R.; Südhof, T.C. A broken alpha-helix in folded $\alpha$-synuclein. J. Biol. Chem. 2003, 278, 15313-15318.

133. Kubo, S.; Nemani, V.M.; Chalkley, R.J.; Anthony, M.D.; Hattori, N.; Mizuno, Y.; Edwards, R.H.; Fortin, D.L. A combinatorial code for the interaction of $\alpha$-synuclein with membranes. J. Biol. Chem. 2005, 280, 31664-31672.

134. Ulmer, T.S.; Bax, A.; Cole, N.B.; Nussbaum, R.L. Structure and dynamics of micelle-bound human $\alpha$ synuclein. J. Biol. Chem. 2005, 280, 9595-9603.

135. Bussell, R.; Eliezer, D. Effects of Parkinson's disease-linked mutations on the structure of lipid-associated alpha-synuclein. Biochem. 2004, 43, 4810-4818.

136. Fortin, D.L.; Nemani, V.M.; Voglmaier, S.M.; Anthony, M.D.; Ryan, T.A.; Edwards, R.H. Neural activity controls the synaptic accumulation of alpha-synuclein. J. Neurosci. 2005, 25, 10913-10921.

137. Cole, N.B.; Murphy, D.D.; Grider, T.; Rueter, S.; Brasaemle, D.; Nussbaum, R.L. Lipid droplet binding and oligomerization properties of the Parkinson's disease protein $\alpha$-synuclein. J. Biol. Chem. 2002, 277, 6344-6352.

138. Kim, Y.S.; Laurine, E.; Woods, W.; Lee, S.-J. A novel mechanism of interaction between $\alpha$-synuclein and biological membranes. J. Mol. Biol. 2006, 360, 386-397.

139. Edidin, M. The state of lipid rafts: From model membranes to cells. Annu. Rev. Biophys. Biomol. Struct. 2003, 32, 257-283.

140. Fortin, D.L.; Troyer, M.D.; Nakamura, K.; Kubo, S.; Anthony, M.D.; Edwards, R.H. Lipid rafts mediate the synaptic localization of $\alpha$-synuclein. J. Neurosci. 2004, 24, 6715-6723.

141. Castagnet, P.I.; Golovko, M.Y.; Barceló-Coblijn, G.C.; Nussbaum, R.L.; Murphy, E.J. Fatty acid incorporation is decreased in astrocytes cultured from alpha-synuclein gene-ablated mice. J. Neurochem. 2005, 94, 839-849.

142. Golovko, M.Y.; Faergeman, N.J.; Cole, N.B.; Castagnet, P.I.; Nussbaum, R.L.; Murphy, E.J. Alpha-synuclein gene deletion decreases brain palmitate uptake and alters the palmitate metabolism in the absence of alpha-synuclein palmitate binding. Biochemistry 2005, 44, 8251-8259.

143. Sharon, R.; Bar-Joseph, I.; Mirick, G.E.; Serhan, C.N.; Selkoe, D.J. Altered fatty acid composition of dopaminergic neurons expressing alpha-synuclein and human brains with alpha-synucleinopathies. J. Biol. Chem. 2003, 278, 49874-49881.

144. Golovko, M.Y.; Rosenberger, T.A.; Feddersen, S.; Cole, N.B.; Pribill, I.; Berger, J.; Nussbaum, R.L.; Murphy, E.J. Acyl-CoA synthetase activity links wild-type but not mutant $\alpha$-synuclein to brain arachidonate metabolism. Biochemistry 2006, 45, 6956-6966.

145. Golovko, M.Y.; Barceló-Coblijn, G.; Castagnet, P.I.; Austin, S.; Combs, C.K.; Murphy, E.J. The role of $\alpha$-synuclein in brain lipid metabolism: A downstream impact on brain inflammatory response. Mol. Cell. Biochem. 2009, 326, 55-66.

146. Kamp, F.; Beyer, K. Binding of alpha-synuclein affects the lipid packing in bilayers of small vesicles. J. Biol. Chem. 2006, 281, 9251-9259.

147. Dikiy, I.; Eliezer, D. Folding and misfolding of alpha-synuclein on membranes. Biochim. Biophys. Acta 2012, 1818, 1013-1018. 
148. Lee, H.-J.; Choi, C.; Lee, S.-J. Membrane-bound $\alpha$-synuclein has a high aggregation propensity and the ability to seed the aggregation of the cytosolic form. J. Biol. Chem. 2002, 277, 671-678.

149. Borghi, R.; Marchese, R.; Negro, A.; Marinelli, L.; Forloni, G.; Zaccheo, D.; Abbruzzese, G.; Tabaton, M. Full length $\alpha$-synuclein is present in cerebrospinal fluid from Parkinson's disease and normal subjects. Neurosci. Lett. 2000, 287, 65-67.

150. El-Agnaf, O.M.A.; Salem, S.A.; Paleologou, K.E.; Cooper, L.J.; Fullwood, N.J.; Gibson, M.J.; Curran, M.D.; Court, J.A.; Mann, D.M.A.; Ikeda, S.; et al. $\alpha$-Synuclein implicated in Parkinson's disease is present in extracellular biological fluids, including human plasma. FASEB J. 2003, doi:10.1096/fj.03-0098fje.

151. Lee, P.H.; Lee, G.; Park, H.J.; Bang, O.Y.; Joo, I.S.; Huh, K. The plasma alpha-synuclein levels in patients with Parkinson's disease and multiple system atrophy. J. Neural Transm. 2006, 113, 1435-1439.

152. Tokuda, T.; Salem, S.A.; Allsop, D.; Mizuno, T.; Nakagawa, M.; Qureshi, M.M.; Locascio, J.J.; Schlossmacher, M.G.; El-Agnaf, O.M.A. Decreased alpha-synuclein in cerebrospinal fluid of aged individuals and subjects with Parkinson's disease. Biochem. Biophys. Res. Commun. 2006, 349, 162-166.

153. Braak, H.; del Tredici, K.; Rüb, U.; de Vos, R.A.I.; Jansen Steur, E.N.H.; Braak, E. Staging of brain pathology related to sporadic Parkinson's disease. Neurobiol. Aging 2003, 24, 197-211.

154. Braak, H.; Ghebremedhin, E.; Rüb, U.; Bratzke, H.; del Tredici, K. Stages in the development of Parkinson's disease-related pathology. Cell Tissue Res. 2004, 318, 121-134.

155. Rubartelli, A.; Cozzolino, F.; Talio, M.; Sitia, R. A novel secretory pathway for interleukin-1 beta, a protein lacking a signal sequence. EMBO J. 1990, 9, 1503-1510.

156. Lecellier, C.-H.; Vermeulen, W.; Bachelerie, F.; Giron, M.-L.; Saib, A. Intra- and intercellular trafficking of the foamy virus auxiliary bet protein. J. Virol. 2002, 76, 3388-3394.

157. Emmanouilidou, E.; Elenis, D.; Papasilekas, T.; Stranjalis, G.; Gerozissis, K.; Ioannou, P.C.; Vekrellis, K. Assessment of $\alpha$-synuclein secretion in mouse and human brain parenchyma. PLOS ONE 2011, doi:10.1371/journal.pone.0022225.

158. Paillusson, S.; Clairembault, T.; Biraud, M.; Neunlist, M.; Derkinderen, P. Activity-dependent secretion of alpha-synuclein by enteric neurons. J. Neurochem. 2013, 125, 512-517.

159. Emmanouilidou, E.; Melachroinou, K.; Roumeliotis, T.; Garbis, S.D.; Ntzouni, M.; Margaritis, L.H.; Stefanis, L.; Vekrellis, K. Cell-produced $\alpha$-synuclein is secreted in a calcium-dependent manner by exosomes and impacts neuronal survival. J. Neurosci. 2010, 30, 6838-6851.

160. Hasegawa, T.; Konno, M.; Baba, T.; Sugeno, N.; Kikuchi, A.; Kobayashi, M.; Miura, E.; Tanaka, N.; Tamai, K.; Furukawa, K.; et al. The AAA-ATPase VPS4 regulates extracellular secretion and lysosomal targeting of $\alpha$-synuclein. PLOS ONE 2011, 6, e29460.

161. Denzer, K.; Kleijmeer, M.J.; Heijnen, H.F.; Stoorvogel, W.; Geuze, H.J. Exosome: From internal vesicle of the multivesicular body to intercellular signaling device. J. Cell Sci. 2000, 113, 3365-3374.

162. Davies, B.A.; Babst, M.; Katzmann, D.J. Regulation of Vps4 during MVB Sorting and cytokinesis. Traffic Cph. Den. 2011, 12, 1298-1305.

163. Sung, J.Y.; Park, S.M.; Lee, C.-H.; Um, J.W.; Lee, H.J.; Kim, J.; Oh, Y.J.; Lee, S.-T.; Paik, S.R.; Chung, K.C. Proteolytic cleavage of extracellular secreted $\alpha$-synuclein via matrix metalloproteinases. J. Biol. Chem. 2005, 280, 25216-25224. 
164. Sung, J.Y.; Kim, J.; Paik, S.R.; Park, J.H.; Ahn, Y.S.; Chung, K.C. Induction of neuronal cell death by Rab5A-dependent endocytosis of $\alpha$-synuclein. J. Biol. Chem. 2001, 276, 27441-27448.

165. Zhang, W.; Wang, T.; Pei, Z.; Miller, D.S.; Wu, X.; Block, M.L.; Wilson, B.; Zhang, W.; Zhou, Y.; Hong, J.-S.; et al. Aggregated $\alpha$-synuclein activates microglia: A process leading to disease progression in Parkinson's disease. FASEB J. 2005, 19, 533-542.

166. Park, J.-Y.; Kim, K.S.; Lee, S.-B.; Ryu, J.-S.; Chung, K.C.; Choo, Y.-K.; Jou, I.; Kim, J.; Park, S.M. On the mechanism of internalization of $\alpha$-synuclein into microglia: Roles of ganglioside GM1 and lipid raft. J. Neurochem. 2009, 110, 400-411.

167. Ahn, K.J.; Paik, S.R.; Chung, K.C.; Kim, J. Amino acid sequence motifs and mechanistic features of the membrane translocation of alpha-synuclein. J. Neurochem. 2006, 97, 265-279.

168. Crews, L.; Tsigelny, I.; Hashimoto, M.; Masliah, E. Role of synucleins in Alzheimer's disease. Neurotox. Res. 2009, 16, 306-317.

169. Danzer, K.M.; Krebs, S.K.; Wolff, M.; Birk, G.; Hengerer, B. Seeding induced by $\alpha$-synuclein oligomers provides evidence for spreading of $\alpha$-synuclein pathology. J. Neurochem. 2009, 111, 192-203.

170. Lee, H.-J.; Suk, J.-E.; Bae, E.-J.; Lee, J.-H.; Paik, S.R.; Lee, S.-J. Assembly-dependent endocytosis and clearance of extracellular a-synuclein. Int. J. Biochem. Cell Biol. 2008, 40, 1835-1849.

171. Hansen, C.; Angot, E.; Bergström, A.-L.; Steiner, J.A.; Pieri, L.; Paul, G.; Outeiro, T.F.; Melki, R.; Kallunki, P.; Fog, K.; et al. $\alpha$-Synuclein propagates from mouse brain to grafted dopaminergic neurons and seeds aggregation in cultured human cells. J. Clin. Investig. 2011, 121, 715-725.

172. Cheung, A.Y.; de Vries, S.C. Membrane trafficking: Intracellular highways and country roads. Plant Physiol. 2008, 147, 1451-1453.

173. Matsui, T.; Itoh, T.; Fukuda, M. Small GTPase Rab12 regulates constitutive degradation of transferrin receptor. Traffic 2011, 12, 1432-1443.

174. Chai, Y.-J.; Kim, D.; Park, J.; Zhao, H.; Lee, S.-J.; Chang, S. The secreted oligomeric form of $\alpha$-synuclein affects multiple steps of membrane trafficking. FEBS Lett. 2013, 587, 452-459.

175. Wilms, H.; Rosenstiel, P.; Sievers, J.; Deuschl, G.; Zecca, L.; Lucius, R. Activation of microglia by human neuromelanin is NF- $\mathrm{B}$-dependent and involves p38 mitogen-activated protein kinase: Implications for Parkinson's disease. FASEB J. 2003, 17, 3500-3502.

176. Klegeris, A.; Giasson, B.I.; Zhang, H.; Maguire, J.; Pelech, S.; McGeer, P.L. Alpha-synuclein and its disease-causing mutants induce ICAM-1 and IL-6 in human astrocytes and astrocytoma cells. Fed. Am. Soc. Exp. Biol. 2006, 20, 2000-2008.

177. Lee, H.-J.; Suk, J.-E.; Patrick, C.; Bae, E.-J.; Cho, J.-H.; Rho, S.; Hwang, D.; Masliah, E.; Lee, S.-J. Direct transfer of $\alpha$-synuclein from neuron to astroglia causes inflammatory responses in synucleinopathies. J. Biol. Chem. 2010, 285, 9262-9272.

178. Luk, K.C.; Song, C.; O’Brien, P.; Stieber, A.; Branch, J.R.; Brunden, K.R.; Trojanowski, J.Q.; Lee, V.M.-Y. Exogenous alpha-synuclein fibrils seed the formation of Lewy body-like intracellular inclusions in cultured cells. Proc. Natl. Acad. Sci. USA 2009, 106, 20051-20056.

179. Desplats, P.; Lee, H.-J.; Bae, E.-J.; Patrick, C.; Rockenstein, E.; Crews, L.; Spencer, B.; Masliah, E.; Lee, S.-J. Inclusion formation and neuronal cell death through neuron-to-neuron transmission of $\alpha$-synuclein. Proc. Natl. Acad. Sci. USA 2009, 106, 13010-13015. 
180. Luk, K.C.; Kehm, V.; Carroll, J.; Zhang, B.; O’Brien, P.; Trojanowski, J.Q.; Lee, V.M.-Y. Pathological $\alpha$-synuclein transmission initiates Parkinson-like neurodegeneration in nontransgenic mice. Science 2012, 338, 949-953.

181. Sacino, A.N.; Brooks, M.; McGarvey, N.H.; McKinney, A.B.; Thomas, M.A.; Levites, Y.; Ran, Y.; Golde, T.E.; Giasson, B.I. Induction of CNS $\alpha$-synuclein pathology by fibrillar and non-amyloidogenic recombinant $\alpha$-synuclein. Acta Neuropathol. Commun. 2013, doi:10.1186/2051-5960-1-38.

182. Diógenes, M.J.; Dias, R.B.; Rombo, D.M.; Miranda, H.V.; Maiolino, F.; Guerreiro, P.; Näsström, T.; Franquelim, H.G.; Oliveira, L.M.; Castanho, M.A.; et al. Extracellular alpha-synuclein oligomers modulate synaptic transmission and impair LTP via NMDA-receptor activation. J. Neurosci. 2012, 32, 11750-11762.

183. Melachroinou, K.; Xilouri, M.; Emmanouilidou, E.; Masgrau, R.; Papazafiri, P.; Stefanis, L.; Vekrellis, K. Deregulation of calcium homeostasis mediates secreted $\alpha$-synuclein-induced neurotoxicity. Neurobiol. Aging 2013, 34, 2853-2865.

184. Ronzitti, G.; Bucci, G.; Emanuele, M.; Leo, D.; Sotnikova, T.D.; Mus, L.V.; Soubrane, C.H.; Dallas, M.L.; Thalhammer, A.; Cingolani, L.A.; et al. Exogenous $\alpha$-synuclein decreases raft partitioning of Cav2.2 channels inducing dopamine release. J. Neurosci. 2014, 34, 10603-10615.

185. Lücking, C.B.; Brice, A. Alpha-synuclein and Parkinson's disease. Cell. Mol. Life Sci. 2000, 57, 1894-1908.

186. Jensen, P.H.; Hager, H.; Nielsen, M.S.; Hojrup, P.; Gliemann, J.; Jakes, R. $\alpha$-Synuclein binds to tau and stimulates the protein kinase A-catalyzed tau phosphorylation of serine residues 262 and 356. J. Biol. Chem. 1999, 274, 25481-25489.

187. Jensen, P.H.; Islam, K.; Kenney, J.; Nielsen, M.S.; Power, J.; Gai, W.P. Microtubule-associated protein $1 \mathrm{~B}$ is a component of cortical Lewy bodies and binds alpha-synuclein filaments. J. Biol. Chem. 2000, 275, 21500-21507.

188. D’Andrea, M.R.; Ilyin, S.; Plata-Salaman, C.R. Abnormal patterns of microtubule-associated protein-2 (MAP-2) immunolabeling in neuronal nuclei and Lewy bodies in Parkinson's disease substantia nigra brain tissues. Neurosci. Lett. 2001, 306, 137-140.

189. Esposito, A.; Dohm, C.P.; Kermer, P.; Bähr, M.; Wouters, F.S. $\alpha$-Synuclein and its disease-related mutants interact differentially with the microtubule protein tau and associate with the actin cytoskeleton. Neurobiol. Dis. 2007, 26, 521-531.

190. Alim, M.A.; Ma, Q.-L.; Takeda, K.; Aizawa, T.; Matsubara, M.; Nakamura, V.; Asada, A.; Saito, T.; Kaji, H.; Yoshii, M.; et al. Demonstration of a role for a-synuclein as a functional microtubuleassociated protein. J. Alzheimers Dis. 2004, 6, 435-442.

191. Liu, G.; Wang, P.; Li, X.; Li, Y.; Xu, S.; Uéda, K.; Chan, P.; Yu, S. Alpha-synuclein promotes early neurite outgrowth in cultured primary neurons. J. Neural Transm. 2013, 120, 1331-1343.

192. Geddes, J.W. a-Synuclein: A potent inducer of tau pathology. Exp. Neurol. 2005, 192, 244-250.

193. Duka, T.; Duka, V.; Joyce, J.N.; Sidhu, A. Alpha-synuclein contributes to GSK-3beta-catalyzed tau phosphorylation in Parkinson's disease models. Fed. Am. Soc. Exp. Biol. 2009, 23, 2820-2830.

194. Garcia, M.L.; Cleveland, D.W. Going new places using an old MAP: Tau, microtubules and human neurodegenerative disease. Curr. Opin. Cell Biol. 2001, 13, 41-48. 
195. Gąssowska, M.; Czapski, G.A.; Pająk, B.; Cieślik, M.; Lenkiewicz, A.M.; Adamczyk, A. Extracellular $\alpha$-synuclein leads to microtubule destabilization via GSK-3 $\beta$-dependent tau phosphorylation in PC12 cells. PLOS ONE 2014, doi:10.1371/journal.pone.0094259.

196. Bellani, S.; Mescola, A.; Ronzitti, G.; Tsushima, H.; Tilve, S.; Canale, C.; Valtorta, F.; Chieregatti, E. GRP78 clustering at the cell surface of neurons transduces the action of exogenous alpha-synuclein. Cell Death Differ. 2014, 21, 1971-1983.

197. Lakso, M.; Vartiainen, S.; Moilanen, A.-M.; Sirviö, J.; Thomas, J.H.; Nass, R.; Blakely, R.D.; Wong, G. Dopaminergic neuronal loss and motor deficits in Caenorhabditis elegans overexpressing human alpha-synuclein. J. Neurochem. 2003, 86, 165-172.

198. Feany, M.B.; Bender, W.W. A Drosophila model of Parkinson's disease. Nature 2000, 404, 394-398.

199. Yamada, M.; Iwatsubo, T.; Mizuno, Y.; Mochizuki, H. Overexpression of $\alpha$-synuclein in rat substantia nigra results in loss of dopaminergic neurons, phosphorylation of $\alpha$-synuclein and activation of caspase-9: Resemblance to pathogenetic changes in Parkinson's disease. J. Neurochem. 2004, 91, 451-461.

200. Nuber, S.; Harmuth, F.; Kohl, Z.; Adame, A.; Trejo, M.; Schönig, K.; Zimmermann, F.; Bauer, C.; Casadei, N.; Giel, C.; et al. A progressive dopaminergic phenotype associated with neurotoxic conversion of $\alpha$-synuclein in BAC-transgenic rats. Brain 2013, 136, 412-432.

201. Lo Bianco, C.; Ridet, J.-L.; Schneider, B.L.; Déglon, N.; Aebischer, P. $\alpha$-Synucleinopathy and selective dopaminergic neuron loss in a rat lentiviral-based model of Parkinson's disease. Proc. Natl. Acad. Sci. USA 2002, 99, 10813-10818.

202. Kirik, D.; Annett, L.E.; Burger, C.; Muzyczka, N.; Mandel, R.J.; Björklund, A. Nigrostriatal $\alpha$-synucleinopathy induced by viral vector-mediated overexpression of human $\alpha$-synuclein: A new primate model of Parkinson's disease. Proc. Natl. Acad. Sci. USA 2003, 100, 2884-2889.

203. Van derPutten, H.; Wiederhold, K.-H.; Probst, A.; Barbieri, S.; Mistl, C.; Danner, S.; Kauffmann, S.; Hofele, K.; Spooren, W.P.; Ruegg, M.A.; et al. Neuropathology in Mice Expressing Human a-synuclein. J. Neurosci. 2000, 20, 6021-6029.

204. Gomez-Isla, T.; Irizarry, M.C.; Mariash, A.; Cheung, B.; Soto, O.; Schrump, S.; Sondel, J.; Kotilinek, L.; Day, J.; Schwarzschild, M.A.; et al. Motor dysfunction and gliosis with preserved dopaminergic markers in human $\alpha$-synuclein A30P transgenic mice. Neurobiol. Aging 2003, 24, $245-258$.

(C) 2015 by the authors; licensee MDPI, Basel, Switzerland. This article is an open access article distributed under the terms and conditions of the Creative Commons Attribution license (http://creativecommons.org/licenses/by/4.0/). 